\title{
Informal institutions and firm valuation
}

\author{
Professor Christopher A. Hartwel1* \\ Department of Finance, Accounting, and Economics \\ Bournemouth University \\ Department of International Management \\ Kozminski University \\ $\&$ \\ Dr. Anna P. Malinowska \\ CASE-Center for Social and Economic Research \\ Warsaw, Poland
}

\begin{abstract}
Research on the effects of the institutional environment on firm market valuation have concentrated on formal institutions and in particular legal frameworks. However, changes in formal institutions may have little to no effect on the deeply ingrained socio-economic processes which determine the way of conducting business in a country. In such a situation, informal institutions may play a much more important role for firms. Using property rights as an example, this paper models the impact of formal and informal institutional changes on the market growth potential of Polish firms. Our examination indicates that Poland's formal and informal institutions diverge significantly, with changes in informal institutions shaping market worth much more than binding formal frameworks. We conclude that firm valuation in an unstable institutional environment is due mostly to developments in informal property rights and other factors external to the firm, with comparatively little effect of firm-specific attributes.
\end{abstract}

Keywords: informal institutions; firm valuation; property rights; emerging markets; Poland

JEL classification codes: P34; G32; O16

ACKNOWLEDGEMENTS: The authors wish to thank Carol Alexander, Ruben Enikolopov, George Filis, Jens Hölscher, Marjorie Lyles, Seung Ho (Sam) Park, Timothy Devinney, Buddy Ungson, Alvaro Cuervo-Cazurra, Elodie Douarin, Randolph Bruno, and seminar participants at UCL for their excellent comments and suggestions on the many earlier drafts of the paper.

*Corresponding author, chartwell@bournemouth.ac.uk, +44771 4018271

\section{POSTPRINT VERSION}

The published Version of Record is available here: 10.1016/j.ememar.2019.03.001

(C) 2019 This postprint version is made available under the CC-BY-NC-ND 4.0 license http://creativecommons.org/licenses/by-nc-nd/4.0/ 


\section{Introduction}

Theories on how markets determine firm value have unsurprisingly been dominated by a focus on the firm's behavior first and foremost, encapsulated in firm-specific attributes. A long literature has shown the predominance of such factors empirically, with company-level traits such as age (Pastor and Veronesi 2003), expected profitability (Varaiya et al. 1987), operating efficiency (Krishnaswami and Subramaniam 1999), investment in tangible assets (Hirschey and Spencer 1992), leverage (Ghosh 2007), and size (Fama and French 1993, 1995) impacting firm returns to varying degrees.

Another important, yet underresearched, stream of the financial literature has highlighted the significance of country institutional attributes (Bruno and Claessens 2010), pointing to how institutional systems inimical to transmission of information can lead to firm valuations fraught with uncertainty and substantially mis-priced (Enikolopov et al. 2014). And while firms may adapt to such environments with stronger internal governance in a bid to signal to markets strength (Durnev and Kim 2005), there may still be a penalty applied to firm valuations in lowquality institutional environments (La Porta et al. 2002).

However, much of the work done on examining institutional frameworks and their influence on firm market value has focused mainly on formal, legal frameworks or governmental institutions as the sum total of a country institutional structure. This approach is defensible given the visibility, influence, and variety of forms of formal institutions (as well as ease of quantification via various governance metrics), as well as abundant theory on how formalised investor protection mechanisms affect company market value. Unfortunately, this approach begins to break down in environments where such frameworks are absent or weak, but where business continues to operate and even thrive. Indeed, the fact that formal institution are largely non- 
existent in a country does not necessarily mean that their fundamental roles (i.e., facilitating information flows, supervision and sanctioning, or contract enforcement, see Khanna and Palepu [1997]) are entirely absent. In fact, if such voids do emerge, they are promptly filled by informal institutions which bridge individuals and formal institutions. The fact that business does continue, even in an environment of pervasive formal institutional "voids" (Khanna et al. 2005), means as well that firms and agents must be relying on informal institutional realities (Gao et al. 2017) and their own ingenuity (Durnev and Kim 2005).

A crucial adjunct to this reality is that, as both research and business practice has shown, the functioning of institutions at the informal level often diverges substantially from legislative texts (Doidge et al. 2007), especially in emerging or transition economies (Williams and Vorley 2015). ${ }^{1}$ This further complicates research into the firm, as we may be drawing incorrect conclusions regarding the effect of institutions on firms and how they are valued: are businesses basing their decisions on the law as written? Or are they planning and formulating strategy in response to the actual conditions they encounter on a daily basis (Tonoyan et al. 2010; Sauerwald and Peng 2013)? Which strategy has more weight in determining a firm's worth, formal institutional promises or informal realities?

This paper seeks to explore these questions by examining informal institutional influence on firm market valuation in the specific context of a volatile post-transtion economy. We agree with Stephan et al. (2015:309) that "human behavior is shaped jointly by the constraints, incentives, and resources provided by formal and informal institutions, which can be more or less compatible with each other." Our investigation focuses precisely on the situation where formal institutions are not more but actually less compatible with informal ones; our working

\footnotetext{
${ }^{1}$ This was the source of Milka Casanegra de Jantscher's (1990:179) famous quip that "tax administration is tax policy."
} 
hypothesis is that formal institutional changes in an emerging or post-transition economy may have little to no effect on company market growth potential, if the distance of the reform from the practices of informal institutions is too great.

Our testing ground for this concept consists of two components: first, specific institutions within an institutional structure (both formal and informal) may have disparate impacts on the firm (Zheng et al. 2012; Choi et al. 2016). Given this reality, we focus on property rights as the most appropriate institution of interest, as the proper functioning of property rights decreases transaction and monitoring costs for business partners, facilitating company-level transparency and creating valuations which better reflect "true" value (La Porta et al. 2002, Knyazeva et al. 2013, Enikolopov et al. 2014). Additionally, property rights also have the benefit of being extensively studied and quantified, with the various relevant quantitative measures of property rights having different underlying assumptions (Williams and Siddique 2008). The second component of our analysis exploits these differences econometrically in order to differentiate between "formal" and "informal" institutions: utilizing the commonly-used ICRG index of contract viability to proxy for formal institutions and the Clague et al. $(1996,1999)$ measure of contract-intensive money to proxy for informal institutions, we can reveal the effects of informal institutions in an empirical analysis of firms in a specific economy.

Poland, a volatile-yet-advanced emerging economy, was chosen as the test case for this analysis, as it has been subject to large formal institutional upheaval over a short period of time but with correspondingly slower change in its informal institutional structures. Moreover, analyses of firm market value remain scarce in the context of advanced emerging markets such as Poland (Malinowska 2018), Our analysis uses this institutional divergence to ascertain the 
nature of its impact on firm valuation, a firm attribute which shaped heavily by (and sensitive to) the institutional environment (Durnev and Kim 2005).

Our results, while not necessarily quantifying the size of the gap between formal and informal property rights in Poland, do show that the gap does exist at a substantive level and has persisted throughout the transition and in particular in the post-EU accession period. More importantly, this study reveals that the informal institutional sphere matters more than formal institutions in their effect on market growth of Polish firms. Using dynamic panel data methods to econometrically analyse formal and informal property rights, we show that, while formal legislative indicators appear to have a negative impact on the market positions of Polish firms, changes in our preferred measure of informal property rights correlated positively with increasing firm market potential and dwarfed the effects of the formal business environment. We conclude that formal institutional changes are likely to have an effect on firms only if these reforms are aligned with informal institutional realities.

\section{Theoretical Background and Hypotheses}

\section{Informality and firms}

Stephan et al (2015:310) conceptualize informal institutions as "slowly changing, culturally transmitted and socially constructed institutions." As with formal institutions, informal ones are often perceived as existing in order to facilitate socio-economic processes, i.e., reduce transaction costs, resolve information asymmetries, and encourage certain behaviors either by group members or outsiders (Hartwell 2013). In weak institutional environments, informal institutions may substitute for formal institutional mechanisms such as financial markets or the judiciary, crafting a local solution to a national void. Yet, informal institutions may also prove a hindrance as well, creating pressures for compliance (Maksimov et al. 2017) which may be 
difficult for outsiders to achieve either legally or culturally; indeed, this function may be more commonly found in informal institutions than in formal ones, as lack of knowledge about the local ways of conducting business (iterative processes themselves which may have evolved to advantage certain groups) likely creates market entry barriers for foreign firms.

The role of informal institutions in the make-up of the business environment, coupled with their force of moral suasion and/or other forms of sanctioning, means that they necessarily influence not only how business is conducted but also how it is perceived. Informal institutions may precipitate changes in its behavior to comport with cultural and professional norms beyond the formal institutional realm (Minbaeva and Muratbekova-Touron 2013), yet their impact needs not stop at firm strategy. In reality, informal normative institutions may potentially shape all dimensions of corporate up to and including assessment by market players (see Figure 1). This impact of informal institutions on firm operation and valuation is heightened if formal institutional structures are weak or, less obviously, in a situation where formal and informal institutions are in conflict. The latter situation may arise from formal policy or institutional changes aiming explicitly to either alter cultural tenets or break the barriers to business erected by informal institutions. Indeed, many formal reforms may be implemented with apparent lack of societal logic - in other words they are incompatible at time $t$ with the societies in which they are ostensibly based. Then, with such rules not internalized by society, compliance can be achieved under political or legal pressure.

\section{[FIGURE 1 HERE]}

The gulf between formal and informal institutions can persist for years, if not decades. Even if temporary, such disjoint puts an economy in an unstable and non-equilibrium position - at some 
point, either culture or power will assert itself to become the dominant (if not sole) institutional matrix, and informal rules may become institutionalized and condition the types of exchanges allowed (Chacar et al. 2010). Informal sanctions and practices may need a generation to pass from the scene, while formal political institutions may require successive rounds of voting and political will to converge with informal practice - again meaning a long period of disequilibrium. We thus hypothesise that this violent divergence of the formal and informal creates the real "institutional void," challenging businesses to navigate between a country's two poles of formal and informal rules (and its many sub-poles of informality).

Transition economies, where "fundamental and comprehensive changes [are] introduced to the formal and informal rules of the game"' (Peng, 2003: 275), appear a special case in point, as they represent an entire institutional system in a state of flux. Characterized by rapid and substantial institutional changes at the formal level, often introduced as part of a large package and done concurrently with macroeconomic stabilization reforms, such formal developments are necessarily implemented without similar comprehensive changes in informal institutions (Maksimov et al. 2017). The latter, by definition, cannot be imposed from above, meaning that the divergence between formal and informal institutions may be particularly pronounced in a transition economy (Williams and Vorley 2015). While formal institutional changes usually aim to bring new or reformed formal institutions closer to the informal reality (especially with regard to commerce), that is, unfortunately, not always the case and the exogenously-inspired reforms end creating large institutional voids between formality and informality (see Hartwell [2014] for the specific example of capital markets). In such an environment fraught with institutional uncertainty, firm market entry and business strategy are even more difficult to set; at the same time, firm performance measurement methods and credibility of market-based company valuations are called into question. 
One of the key institutions at the heart of the transition process is economic and legal property rights, the basis for a market economy and an institution formally eradicated under decades of communism. Countless research has established the importance of good property rights for firm performance, as they are one of the institutions to affect the firm throughout the entire continuum shown in Figure 1: in the first instance, property rights have been shown to be crucial for firm performance, structuring the incentives of firms towards productive activities (Baumol 1990); moreover, quality property rights will reduce costs of production for firms, as well as enable contractual relations with suppliers and other agents (Yasar et al. 2011).

More suited to our purposes, property rights should directly correlate with firm valuation, as "firms operating in an environment with insecure property rights are uncertain about their ability to keep the fruits of their efforts and as a consequence, decrease their investment activities" (Berkowitz et al. 2015:583). Additionally, Hail and Leuz (2006) show that poor property rights translate into higher costs of equity, while Djankov et al. (2007) note that legal reforms assuring investor protection result in higher levels of credit to the private sector. Finally, efficient property rights laws incentivises greater information-sharing without the fear of being penalised (Enikolopov et al. 2014; Rodrik et al. 2004) and mitigates firm-level transparency management, presumably leading to more accurate firm valuation. Improved informational transparency then facilitates access to external financing or more profitable, longterm deployment of existing assets, such as research and development and building human capital (Fan et al. [2012] show that property rights influence firm capital structures and reliance on debt). 


\section{Research Hypotheses}

Given the likely divergence of formal and informal institutions in transition, and given the importance of both formal and informal property rights for business performance, this paper advances two hypotheses:

H1: Formal and informal property rights institutions did diverge in transition economies and this divergence has persisted

This first hypothesis challenges us to prove that there actually was a divergence between formal and informal property rights in transition economies; with no divergence, the importance of informal institutions will likely be minimal and subsumed to formal institutions.

The obstacle in proving this hypothesis comes from the inherent difficulty in quantitatively measuring informal institutions. Subjective indicators have been the most commonly utilized in the literature to proxy for institutions, and with apparently good reason: as Grogan and Moers (2001:326) notes, subjective measures "are likely to reflect concerns about the quality of institutions more closely and directly." Unfortunately, subjective indicators have certain shortcomings: indeed, "subjective evaluations are tainted by the theories, ideologies, prejudices, and so forth of the respondent" (Voigt 2013:18-19).

This taint may extend to confusion on what is actually being measured: as Glaeser et al. (2004) argue, many institutional indicators mix, to a varying degree, both institutional factors and policy. More relevant for our purposes, subjective indicators are commonly based on perception of a country's formal institutions rather than the actual functioning of various institutions on the ground. This point has been made in reference to property rights indicators and their 
relationship with growth: Williamson and Kerekes (2011), in particular, argue that subjective indicators (in this case, the ICRG index) of property rights are outcome variables, ones that do "not reflect permanent political constraints because [they] rise with per capita income.",

The same criticism can be made about subjective indicators when thinking of the relationship between formal laws and informal norms. The formal institutional changes accompanying transition can create the mirage of institutional change, without touching the cognitive and normative functions of informal institutions. In extreme cases, the perception of institutional change, embodied in legislative change, may be entirely illusory, as informal institutions and social currents may impede the actual institutional transformation. Under such a scenario, indices would reflect the letter of the law, a proposed change to formal institutions, rather than an actual institutional shift. ${ }^{3}$ Our quantification of a country's institutional quality would thus be based on the idealized conception of formal institutions as embodied in law rather than the actual formal and informal institutional functioning of a particular country. ${ }^{4}$

Objective indicators, on the other hand, rely on readily observable, ex-post indicators that could theoretically proxy for the functioning of informal institutions within an economy. Objective metrics, since they are explicit in capturing economic outcomes of an efficient institutional system and not just formal legislation, could be more preferable to subjective metrics in social sciences. Yet, such metrics are often crude and encompass much more than the main desired effect. With very few true variables to be observed ex-post to show that property rights are

\footnotetext{
${ }^{2}$ While their argument appears to come down in favour of subjective indicators (due to the ICRG index ostensibly encompassing formal and informal institutions), it notably avoids the issue of informal institutions, which is crucial to our argument.

${ }^{3}$ Moreover, a change in a subjective institutional index on the occasion of a legislative change would necessarily predate the actual institutional change, as formal institutions can also be slow-moving.

${ }^{4}$ From a technical point of view as well, the ICRG indices, as opposed to metrics published by Polity IV or the Heritage Foundation, display significant variation over time in the short term.
} 
being enforced or that a judiciary is independent we are left observe institutions in the breach rather than in practice, seeing that effective property rights do not generate events per se (i.e. we are looking for the dog that doesn't bark). But, given that objective indicators capture outcomes by design, they may approximate informal institutional influence better than the potential formal institution desired by a piece of legislation.

With regard to property rights, this difference between subjective and objective can also map neatly to the differences between formal and informal property rights. In particular, we assert that a subjective indicator of property rights, the ICRG index on contract viability (henceforth ICRG CV), can trace the development of the formal sphere of property rights institutions. The ICRG CV is an index which defines property rights and the extent of their security as a function of their danger of being expropriated by the ruling government (coded on a scale from 1 to 4 , with higher numbers corresponding to higher property rights). It is this focus on the interaction of the private and the public sector which makes the $\mathrm{CV}$ measure an excellent guide to understanding the formal institutional framework of property rights, as it explicitly excludes informal arrangements and only focuses on the threat of expropriation by formal political authorities

To quantify informal property rights, we also assert than an objective indicator can be the best approximation of informal institutions; for this, we turn to contract-intensive money (CIM), measured as the percentage of money held inside the formal financial (i.e. banking) sector as a proportion of all money. Its underlying concept is that strong property rights, i.e. those which are protected at any point by a strong network of institutions, will draw money into the formal financial sector. CIM thus assumes that stronger social values corresponding to both legal and economic property rights of individuals, not necessarily enforced on pain of criminal 
prosecution or otherwise, reflect greater formal financial sector participation at the level of society (Clague et al. 1999). ${ }^{5}$ Indeed, in its objectivity, CIM aims to track a society's collective actions in response to socio-institutional (r)evolution rather than relying on individual subjective evaluation of legislation. While, as a quantitative measure, it likely captures more than solely informal institutional workings, it is a much better proxy for informality than external expert-based indices tracking contemporaneous legislative changes. ${ }^{6}$

H2: Informal normative property rights institutions are more important for firm valuation in transition

Theories on how markets determine firm value has, not surprisingly, been dominated by a focus on the firm's behavior first and foremost, encapsulated in firm-specific factors such as age (Pastor and Veronesi 2003), expected profitability (Varaiya et al. 1987), operating efficiency (Krishnaswami and Subramaniam 1999), leverage (Ghosh 2007), and size (Fama and French 1993, 1995). However, it is not enough for a firm to be performing well in order to have an accurate (and high) valuation; it is also of crucial importance that such information be communicated to markets to create an accurate picture of current and future firm prospects, and the fact that obtaining such information may have a high or prohibitive cost in some environments may mean that firm valuation is reliant on more than just firm behavior.

\footnotetext{
${ }^{5}$ Guiso et al. $(2004,2008)$ also report that trust, a key informal institution, accounts for wider equity market participation, a mechanism which is also assumed in CIM.

${ }^{6}$ The application of a purely financial indicator to capture institutional development of a country may be perceived as misguided, and Williams and Siddique (2008) remarked that CIM could better proxy for the state of a country's financial system as opposed to property rights. However, as noted in Hartwell $(2014,2016)$, the financial system of any country is slow-changing and the application of high-frequency data to calculate CIM allows to capture shifts in realized property rights rather than financial sector development. Moreover. use of CIM is not recent by any means (Clague et al. 1996) and has been used extensively in the literature.
} 
The key mechanism via which financial information is transmitted is of course the price system, but the price system itself is shaped, embedded, and operated within a country's institutional structures. If an institutional system inimical to transmission of information, or one which increases transaction costs for obtaining information, it can be expected that firm valuations will be fraught with uncertainty and can be substantially mis-priced. Moreover, the actual information being communicated can be different depending upon who is doing the judgment, i.e. if firm-specific performance is being judged by formal institutions or by informal ones (as noted above, La Porta et al. [2002] find firm valuations in low-quality institutional environments suffer a penalty).

In line with Hypothesis 1, we hypothesize (as others have noted) that formal institutions are important for firm valuation; however, where informal institutions are misaligned with formal institutions, it is informal institutions which will predominate in assessing a firm's performance. Taking the example of property rights, formal legislation on contract enforcement may indeed correlate with higher firm valuation as such rights have a salutary effect on financial sector development, as noted above. But Besley and Ghatak (2010) make a case that not only are there many situations where contract enforcement is best handled in a local, informal setting, but also access to finance may be easier informally (especially if a financial sector is weak, fragmented, or requires political connections to enter).

That this is indeed the case in transition economies, as lack of opportunities further afield means that a firm's suppliers or customers were likely to be local, leading to less incentive to renege on contracts (McMillan and Woodruff 2002). Similarly, local or industry-specific enforcement mechanisms meant that companies which failed to comport in line with informal expectations were punished in terms of their performance (McMillan and Woodruff [2002] use the example 
of gossip amongst Vietnamese firms). From the negative side, informal institutions such as organized crime, squatters, and social groups may predominate at the local level over legislative changes, making the legal claims of firms less secure and subject to more negotiation and transactions than legislation would assume (Lanjouw and Levy 2002).

Given the influence of informal institutions in situations where state capacity or enforcement is low (i.e. most transition and emerging market economies), a firm's value would thus not depend on formal property rights protection as embodied in law, but on the way in which the firm interacted with (and was able to satisfy) informal property rights institutions. Put another way, even though formal property rights changes may move in a direction which would be beneficial to a firm, firm performance and valuation may not shift if informal institutions do not also follow. We surmise that such formal changes would have little effect or possibly even a negative one on firm valuation, if they forced a firm to become misaligned with realities on the ground in the name of harmonizing with formal institutions (which themselves are misaligned). In a country where there is a substantial institutional distance between formality and informality, firms will only improve their performance by catering to informal institutions.

\section{Hypothesis 1: The Case of Poland}

Poland, a high-performing post-transition economy, is an excellent case for observing the divergence between formal and informal property rights and what effect this had on firm market-based pricing mechanisms. In fact, Poland stands out among other CEE economies as a country in which property rights never ceased to be, even at the height of socialism. Hartwell (2016: 147-148) notes that "the socialist envelopment of the economy was not as extensive as elsewhere in the region" and "only 63 percent of national product came from the socialized sector, lowest among all Soviet bloc countries.” After joining the EU in 2004, it was anticipated 
that the legal framework for property rights would remain at a fairly high and consistent level. However, even at this late stage of transition, a gulf between what was being proposed at the government level and what was actually occurring on the ground remained discernible; subsequent changes in formal judicial frameworks (2007-2015) served only to widen the rift.

To illustrate this divergence in Poland (and thus validate our first hypothesis), we use the two metrics of institutional development noted in the previous section. Poland's formal property rights framework over 2007 to 2015, measured by the ICRG CV measure, remained inconsistent, with substantial fluctuations corresponding to legislative and regulatory changes during this timeframe (Figure 2). The largest reform was the introduction of an Act on Court Bailiffs and Debt Collections liberalising the bailiff profession. ${ }^{7}$ This breaking up of the quasimonopoly of the bailiffs (Józefowicz 2007), precipitated an increase in (formal) institutions in the first quarter of 2008. Further legislative developments in September 2011 amounting to an amendment to the Code of Civil Procedure and later in the first quarter of 2012 a $20 \%$ reduction in the number of first-instance courts reversed these gains. ${ }^{8}$

Institutional change likely eludes synthetic indices, as these measures track policies and not institutions creating them - thus it is perhaps more instructive to think of them as Type II policies designed to affect institutions but not fuel institutional change per se (Williams and Siddique 2008). This illustrates our point, as reforms in the formal legislative environment do not necessarily correspond to changes in a country's overall ingrained institutional setting. They

\footnotetext{
7 At the time of this writing, the Act on Court Bailiffs and Debt Collections have been subject to a staggering number of amendments (30 in the past decade), with the last one entering into force on $28^{\text {th }}$ October 2017.

8 According to 2014 data, Poland reports precisely 0.8 first-instance courts per 100,000 inhabitants, less than half the EU average of 2, See European Commission for the Efficiency of Justice (2016).
} 
may have little effect on informal institutions, even as they are working to change formal institutions ${ }^{9}$.

[FIGURE 2 HERE]

Although the two indicators use different scales, the divergence in trends between the measures is clearly discernible in Figure 2: while formal property rights institutions waned from 2011 onward, informal institutions remained fairly impervious to political maneuvering on property rights (with only some seasonal variation) and actually increased until early $2015 .{ }^{10}$ It is only in Q1 2015 that we detect a noticeable and persistent downturn in the informal practice of property rights in the country, but even by the end of 2015 property rights were still approximately two percentage points higher than they were in the depths of the global financial crisis. Contrasted with formal institutional changes from 2011 to 2014, informal institutions appeared to fill the void, creating an atmosphere of business as usual.

It was not until the election of the current government in 2015 that informal property rights appeared to actually be under threat. This raises an interesting theoretical point regarding internal institutional distance: it seems that some of that distance can always be closed by a

\footnotetext{
${ }^{9}$ We recognize that the argument that formal institutions are also slow-moving, and that there is an institutional distance between legislative changes and institutional change, is manifestly the point of earlier critiques of subjective indicators (as in Glaeser et al. 2004). While we believe this is an important point, as even formal institutions do not change merely because a law does (implementation and administration are crucial), the fact remains that formal institutional change has legislative change as a necessary, if not sufficient, precursor. Thus, there may be distance between formal institutional functioning and legislative change, but our point remains that there is even greater distance between legislative change and informal institutional change. In fact, the larger the gap between legislative change/formal institutional change, the larger the gap will be between legislative changes and informal institutional shifts.

${ }^{10}$ Given the problems inherent in observing shifts in informal property rights at the local, regional, and even country-wide level over a short time period, it is difficult to say why our measure of informal institutions may have improved over this timeframe. We conjecture that there were several issues, including a general change in mood following the political events from end 2009, including the sweeping of the Law and Justice party from the Presidency in early 2010 - as we show below, Law and Justice hold a decidedly non-free-market position and thus informal institutions may have been under threat (see also Figure 3). In addition, improvements in general economic conditions could also have induced more utilization of informal property rights (just because they exist does not mean they will be used, especially if economic conditions are depressed). Put another way, given more opportunities for commerce, but a general perception that formal institutions were in decline, people turned to informal institutions to take advantage of these opportunities.
} 
government willing to deploy massive resources or political will to impose formal institutions over informal ones. Indeed, prior political changes to formal institutions in Poland had little effect at the informal level simply because these changes tinkered with administrative procedures. The elections in 2015 seem to have been qualitatively different, creating a real threat to both formal and informal institutions.

\section{[FIGURE 3 HERE]}

Plotted against CIM, the ICRG's subjective "political risk" indicator (Figure 3), capturing the perception of the threat which formal changes in Poland's government might pose to preservation of established informal socio-economic norms, comprises of several expert-based indices ${ }^{11}$ covering administrative capacities as well as institutional factors. The two indices move in almost exactly the opposite directions over 2007 to 2015: the low level of informal property rights early in the period coincided with elevated political risk, while the final quarter of 2009 brought about certain improvement as the danger of political interference in the business sphere subsided. ${ }^{12}$ In hindsight, it seemed like the quiet before the real storm in form of the 2015 pre-election turmoil and the subsequent victory of the populist government. With the threat of massive formal changes on the horizon, informal institutions were once again under pressure.

\footnotetext{
${ }^{11}$ Including corruption within a country's political system, socioeconomic pressures, and a government's power to carry out its declared goals as well as its potential to stay in office

${ }^{12}$ In particular, the Polish Presidency of the EU and the 2011 Parliament elections won by the center-right Civic Platform (PO) appeared to have instilled confidence in the protection of property rights.
} 


\section{Hypothesis 2: Effects Of Informal Institutions On Firm Valuation}

\section{The Model}

This brief overview of the development of Poland's property rights shows that formal and informal property rights did indeed diverge substantially. Turning to our second hypothesis, how did this divergence affect firms, and in particular, their valuation? In order to formally model the relationship between the effects of the gap between law and implementation on firm valuation, we have compiled a new unbalanced quarterly panel of data encompassing companylevel, institutional, stock, and macroeconomic variables for 218 non-financial entities listed on the Warsaw Stock Exchange (WSE) from 2007 to 2015 (Tables A1, A2, and A3 in the Appendix show the detailed description, source information, summary statistics, and correlations for each variable). ${ }^{13}$

Our baseline equation for this analysis is:

$$
Y_{i, t}=\alpha \operatorname{INSTITUTIONS}(t-1)+\beta \text { FIRM }_{i,(t-1)}+\gamma \operatorname{MACRO}_{(t-1)}+\delta \text { Period }+\varepsilon_{i, t}
$$

where $Y_{i, t}$ denotes the observed change in relative firm market value (expressed as a log change in the firm price-earnings ratio (P/E) measured year-over-year) while Period $_{i}$ controls for time, and $\varepsilon_{i, t}$ represents unobserved firm- and sectoral-level fixed effects. ${ }^{14}$ We base our choice of the dependent variable on its ease of interpretation, as well as documented use both in financial analyses and academic research (e.g. Fama and French 1993, 1995, 2015; Foye and Mramor 2013, 2016). The extant literature also highlights P/E's utlisation among other commonly-used multiples such as price-to-earnings or price-to-sales ratios (as well as metrics

\footnotetext{
13 The data was winsorized at the $1 \%$ level to remove the most extreme outliers.

${ }^{14} \mathrm{We}$ are well aware that this approach would be insufficient had we decided to capture the interactions between institutional and industry factors. Such effects could provide valuable insights, especially with regard to more formalised and state-dependent sectors. However, given the size and nature of our sample it is probable that certain industries could be underrepresented, therefore introduction of industry effects could potentially yield biased results.
} 
based on cash flow, such as enterprise value relative to earnings before interest and taxes) in firm market valuation (see especially Lie and Lie 2002, Fama and French 2002, and Cheung et al. 2009). Relevant contemporary research has relied on what has been commonly, yet mistakenly, taken for Tobin's q to approximate firm market value in the context of changing firm internal and external factors. Looking back at the original Tobin's $q$ and its intended role as a macroeconomic investment policy modelling tool, we argue that the current version utilised in corporate finance is not only dubiously grounded in theory but also does not capture what the majority of academic researchers believe it to do. With Tobin's q being clearly unsuitable for the pursposes of this study, we decided to take the road less travelled and rely on the $\mathrm{P} / \mathrm{E}$ ratio as, even if imperfect in many ways, by all apearances less unreliable than the q metric (for a broader account of these issues, see Appendix B).

In the Polish case, the $\mathrm{P} / \mathrm{E}$ for each of the 218 firms in our sample needed to be assembled individually, hand-collected and calculated from data provided by Stooq (a publicly-available domestic source of company market data and one commonly used in scholarly literature). Our main vector of interest, INSTITUTIONS $S_{t-1}$, captures the divergence between formal and informal property rights institutions; it includes the key property rights variables as noted above, the ICRG contract viability measure (for formal property rights) and contract-intensive money (for informal rights).

Firm-level determinants of company value are represented by $F I R M_{i,(t-1)}$. It includes firm size, leverage, operating efficiency, and growth opportunities (all shown to be important in the extant literature as in e.g. Charitou and Constantidinis [2004] and Damodaran [2006]). All the firm-specific variables have been retrieved from company periodical financial reports, processed by Notoria Serwis SA, a domestic market data provider. $M A C R O_{t-1}$ accounts for the 
role of the broader economy in firm valuation, focusing specifically on ease of obtaining external financing by firms: to capture this we utilize two facets of the domestic equity market (its quarterly rate of return and volatility) and the state of the Polish banking system (captured by the shifts in the amount of credit available to nonfinancial entities relative to GDP). We also control for inflation, as previous empirical studies on the effect of inflation suggest not only a negative, but also possibly a non-linear impact on firm market pricing, translating into weaker market acitivity (see Boyd et al. 2001) and changes in overall domestic financial depth (M2). ${ }^{15}$ Finally, we also introduce an additional objective indicator from ICRG, the "Economic Risk Rating”(ICRG ERR), to capture economic/market risk via a combination of numerous outcome variables, including the current account as a percentage of GDP and GDP per capita. ${ }^{16}$ The ICRG ERR has the benefit of mirroring (to a certain extent) fluctuations in Polish market risk as captured in the market beta calculated by Damodaran (see Figure A1 in the appendix); we believe that sectoral/contextual factors are already captured in the volatility of the WIG market index. ${ }^{17}$

In choosing an estimator, the relevant literature highlights the problem of pervasive and persistent endogeneity in relation to both institutional and firm-level controls. With this in mind, we fashion a dynamic panel model using a two-step system general method of moments estimator (2-step SYS-GMM) with heteroskedasticity and serial correlation-robust errors using the finite-sample corrected method (Windmeijer 2005). The approach instruments variables

\footnotetext{
${ }^{15}$ While changes in M2 and inflation may be regarded really as two sides of the same coin, they approximate a country's macroeconomic management in two different ways: growth of M2 relative to GDP and quarterly fluctuations in the level of inflation proxy for actions and non-actions of the government and central bank respectively. Collinearity does not appear worrying: as corroborated by the correlation of $+45 \%$; we also report a correlation of $43 \%$ between CIM and GDP changes and of $-21 \%$ between CIM and the ICRG ERR (see Table A3 for details on the magnitude of correlation between all of the variables).

${ }^{16}$ Following on the last note, there is a low level of correlation between the ICRG ERR measure and our measure of GDP per capita growth (0.13), also alleviating concerns about collinearity.

${ }_{17}$ We use Damodaran's (2006) publicly available ex-post annual calculations for Poland, see the data at http://pages.stern.nyu.edu/ adamodar/New_Home_Page/datacurrent.html
} 
using their own lags, and our strategy for this model is to limit the number of instruments to avoid over-proliferation (Roodman 2009); we also report results ensuring that second-order correlation in the first-differenced residuals and correlation between the chosen instruments and the residuals is absent (Arellano and Bover 1995, Blundell and Bond 1998). As a further check against endogeneity, and as shown in Equation 1, we also lag all our explanators by one period, a decision which mitigates against cross-sectional dependence as consistent estimates are obtainable when using the SYS-GMM estimator provided the spatial term is lagged accordingly (Bouayad-Agha and Védrine 2010). ${ }^{18}$

\section{Results}

Table 1 presents the baseline results: in an interesting twist, in none of the four initial models are the firm parameters we utilize statistically significant for firm valuation in Poland. While unusual (since the firm-specific variables used here are standard in the literature), these results are stable across numerous specifications, and it appears that, in Poland over this timeframe at least, firm market pricing may have been determined in greater part by external, as opposed to firm-specific, factors. Given Poland's status as an emerging market, it is perfectly conceivable that external factors also may neutralize the impact of firm-specific ones, including equity market profitability (positively correlated with firm value), inflation (negative), the ICRG economic risk rating (positive), and GDP changes (negative). Between our specifications, we observe some differences in the magnitude of impact of the control variables; however, those are relatively small and dilute neither the strength nor direction of influence of the control set.

\section{[TABLE 1 HERE]}

\footnotetext{
${ }^{18}$ Stationarity of the variables was ensured via a series of unit root tests bas ed on the canonical augmented DickeyFuller test (Table A4 in the Appendix).
} 
More importantly for this examination, shifts in CIM result in significant and upward movements in firm market valuation (Columns 1 and 2). Conversely, changes in formal institutional structures correlate negatively with firm market value, as legislative developments affect firm value in a significant manner, both economically and statistically (Columns 3 and 4). The divergence between formal and informal institutions is most glaring in the scale of the impact of each measure: for example, every $1 \%$ change in informal property rights, corporate market value increases by $4.6 \%$ while it decreases by $1.3 \%$ when considered vis-à-vis formal legal structures. ${ }^{19}$

The results of the baseline equation support our second hypothesis regarding the effect of informal institutions on firm valuation. Indeed, at least in the Polish case, it seems that wellmeant legal reforms to formal property rights institutions instead brought unwanted and unpredicted consequences which obstructed investor rights. Coupled with the evidence shown above, it appears that property rights institutions are better understood within Poland at the informal level rather than in their formal iteration.

[TABLE 2 HERE]

To further test this hypothesis and understand the sensitivity of the baseline results, we extend the analysis to include both measures of formal and informal institutional development in the same regression (Table 2). The obtained evidence underpins our hypotheses, as formal institutions appear to subtract between $1.7 \%$ and $1.9 \%$ from firm market potential with every unit of change. Simultaneously, informal institutions affect firm market value in the opposite direction, adding, all else equal, between $2.1 \%$ and $2.6 \%$. Similar to the first set of regressions,

\footnotetext{
${ }^{19}$ In terms of the adequacy of the model, the conditions necessary for the use of the SYS-GMM estimator are satisfied, with no disturbing second-order correlation and satisfactory Sargan test outcomes on the validity of the instrument set.
} 
firm-specific controls remained of marginal significance, with the $\mathrm{D} / \mathrm{E}$ ratio the only statistically significant factor. Interestingly, the importance of the domestic equity market diminished in terms of statistical significance. At the same time market risk (the IRCG ERR indicator) retained its importance, suggesting a positive correlation between firm market growth potential and economic risk - an observation which aligns, in terms of direction and impact, with the influence of market volatility on firm market valuation.

As a robustness test (Tables 3 and 4), we incorporate other aspects of the domestic and international business environment which could plausibly correlate with firm value. Our nonresults regarding firm-level controls, in particular, may be a quirk of transition, where internal institutional and corporate changes may be less important for firm market valuation than the broader economic environment. To control for the possible role of external factors in firm valuation, exogenous from domestic institutions, we re-run the regressions with the inclusion of shifts in foreign direct investment (FDI) inflows to proxy for firm access to finance. FDI has been shown to ameliorate asset allocation and raise market efficiency, thus boosting firm market potential (Yasar and Paul 2007); however, there is also the possibility that FDI can precipitate substantial competition effects, favoring foreign businesses and lowering domestic firm valuation (Konings 2001). In addition to FDI, given the relatively small size of the Warsaw Stock Exchange and the greater reliance of an emerging market such as Poland on global economic conditions, we also include American and European equity market indices to proxy for the overall global economic situation..$^{20}$

\footnotetext{
${ }^{20}$ With an almost non-existent foreign debt and an annual average ratio of revenues from export to total revenues hitting $0.63 \%$ in 2008 and oscillating between $0.59 \%$ and $0.79 \%$ between 2009 and 2013 (with a high at $0.8 \%$ in 2014), the correlation of Polish firms' market value and international equity market conditions is not as obvious as what could have been expected in relation to the domestic stock market (Authors' own calculations based on the data retrieved from the Notoria Serwis SA database)
} 
[TABLES 3 and 4 HERE]

It seems that the inclusion of FDI in both models does not affect the results of either formal or informal property rights, while FDI itself has an insignificant effect (which might only be supportive of Koning's [2001] insights). With regard to global economic conditions, both international stock markets have a much larger effect on the current market worth of Polish companies than the domestic market: for the model including informal property rights, every $1 \%$ of the S\&P 500's rate of return adds approximately $4.9 \%$ to Polish firm market growth. More importantly, both institutional metrics manifest little change in their effects, meaning that, even accounting for external conditions, it appears that a country's own institutional distance between its informal and formal institutions may negatively impact firm market value. In this case, it seems plausible to conclude that property rights changes at the formal level misaligned with informal institutions, and it was only informal changes which affected firm valuation. ${ }^{21}$

\section{Conclusions}

The impact of informal institutions on firm behavior is a complicated question, one which is only starting to gain traction in the literature as we expand our understanding of institutions in general. This paper has delivered pioneering insights on the diverging influence of formal and informal property rights on firm market value in Poland utilizing a new quarterly dataset of institutional, macroeconomic, and company-level data between 2007 and 2015. In particular,

\footnotetext{
${ }^{21}$ As an additional robustness test, we replaced the dependent variable, the firm $\mathrm{P} / \mathrm{E}$ ratio (which should convey a firm's market potential), with a purely accounting metric, i.e. firm earnings per share (EPS). EPS, calculated as a ratio of firm earnings before tax and its number of shares does not necessarily convey information about market positioning in as effective a manner as the $\mathrm{P} / \mathrm{E}$ ratio but nonetheless often has a positive association with stock prices (Bao and Bao 2004). Given its very nature, we would expect that firm EPS might, in fact, be more sensitive to firm-specific conditions than to external factors. However, the obtained (non) results proved unsatisfactory without changing the initial model specification markedly, we did not detect a statistically significant impact of either internal or external factors, even though the technical parameters (including instrument selection and autocorrelation-related issues) appeared to meet the theoretical prerequisites. Due to these reasons and for the sake of brevity, these results are not included here but results are available from the authors upon request.
} 
our analysis has shown that there was in fact a divergence between formal and informal property rights institutions during this period as demonstrated in two commonly-used metrics for property rights; on the basis of this reality, we also were able to demonstrate that informal rights likely had a more profound influence on firm market valuation than the simple act of changing legislation.

Extensions to this research can take many permutations across economics. In the first instance, this investigation, being an experimental case study, has focused solely on publicly-traded firms in one emerging market economy. Expanding the current analysis by including finer controls for corporate governance, present and past political connections at the firm-level, and/or sectoral trends could yield a better understanding of the importance of the dynamics between the institutional, sector-specific, and political factors in post-transition economies. A more indepth analysis of the relevance of the institutional and market forces effects on company accounting metrics could shed new light on issues related to divergencies between book and market values of firm assets and the resulting misvaluations of businesses. Alternately, using data from smaller, less-formal businesses could help paint a broader picture of the effect of informal institutions on the firms most likely to encounter informality; such a single-country case study approach could also be utilized in other countries around the world. Additionally, this analysis could be replicated in a bilateral or multi-country study, opening the way towards for more understanding of within-country institutional distances, the determinants of informal institutional change, and the effect of informal institutions on other metrics of firm behavior.

Regardless of how these extensions play out, the theoretical framework outlined within this paper has shown that, in the Polish context, firm decisions, and indeed firm value, is not just 
shaped by the institutional environment as shown in formal legislation but by a complex web of supporting, informal institutions. 


\section{References:}

Arellano, M., \& Bover, O. (1995). Another look at the instrumental variable estimation of errorcomponents models, Journal of Econometrics, 68(1): 29-51.

Bao, B. H., \& Bao, D. H. (2004). Income smoothing, earnings quality and firm valuation. Journal of Business Finance \& Accounting, 31(9-10), 1525-1557.

Bartlett, R. P. \& Partnoy, F., (2018) The Misuse of Tobin's Q, UC Berkeley Public Law Research Paper

Baumol, W. J. (1990). Entrepreneurship: Productive, unproductive and destructive. Journal of Political Economy, 98(5), 893-921.

Berkowitz, D., Lin, C., \& Ma, Y. (2015). Do property rights matter? Evidence from a property law enactment. Journal of Financial Economics, 116(3), 583-593.

Besley, T., \& Ghatak, M. (2010). Property rights and economic development. In Rodrik, D., and Rosenzweig, M. (eds.), Handbook of Development Economics (Vol. 5). North Holland: Elsevier, pp. 4525-4595.

Bharath S., Jayaraman S., \& Nagar, V. (2013). Exit as Governance: An Empirical Analysis. The Journal of Finance, 68(6), 2515-2547

Blundell, R., \& Bond, S. (1998). Initial conditions and moment restrictions in dynamic panel data models. Journal of Econometrics 87: 115-143 
Bouayad-Agha, S., \& Védrine, L. (2010). Estimation strategies for a spatial dynamic panel using GMM. A new approach to the convergence issue of European regions. Spatial Economic Analysis, 5(2), 205-227.

Boyd, J. H., Levine, R., \& Smith, B. D. (2001). The impact of inflation on financial market performance. Journal of Monetary Economics 47(2), 221-248.

Brainard, W. C., \& Tobin, J. (1968). Pitfalls in financial model building. The American Economic Review, 58(2), 99-122.

Bruno, V., \& Claessens, S. (2010). Corporate governance and regulation: can there be too much of a good thing? Journal of Financial Intermediation, 19, 461-482.

Casanegra de Jantscher, M. (1990). Administering the VAT. In M. Gillis, C. Shoup and G.P. Sicat (Eds.), Value Added Taxation in Developing Countries. Washington DC: World Bank, pp. 171-190.

Chacar, A. S., Newburry, W., \& Vissa, B. (2010). Bringing institutions into performance persistence research: Exploring the impact of product, financial, and labor market institutions. Journal of International Business Studies, 41(7), 1119-1140.

Charitou, A., \& Constantinidis, E. (2004). Size and Book-to-Market Factors in Earnings and Stock Returns: Empirical Evidence for Japan. In Illinois International Accounting Summer Conferences Working Paper. 
Cheung, Y. L., Qi, Y., Rau, P. R., \& Stouraitis, A. (2009). Buy high, sell low: How listed firms price asset transfers in related party transactions. Journal of Banking \& Finance, 33(5), 914924.

Choi, J. J., Lee, S. M., \& Shoham, A. (2016). The effects of institutional distance on FDI inflow: General environmental institutions (GEI) versus minority investor protection institutions (MIP). International Business Review, 25(1), 114-123.

Clague, C., Keefer, P., Knack, S., \& Olson, M. (1996). Property and contract rights in autocracies and democracies. Journal of Economic Growth, 1: 243-276

Clague, C., Keefer, P., Knack, S., \& Olson, M. (1999). Contract-intensive money: contract enforcement, property rights, and economic performance. Journal of Economic Growth, 4(2), $185-211$

Cull, R., \& Xu, L. C. (2005). Institutions, ownership, and finance: the determinants of profit reinvestment among Chinese firms. Journal of Financial Economics, 77(1), 117-146.

Damodaran, A. (2006). Damodaran on Valuation: Security Analysis for Investment and Corporate Finance, 2nd Edition, John Wiley \& Sons, Inc., Hoboken, NJ, USA ISBN: 978-0$471-75121-2$

Djankov, S., McLiesh, C., \& Shleifer, A. (2007). Private credit in 129 countries. Journal of Financial Economics, 84(2), 299-329. 
Doidge, C., Karolyi, G. A., \& Stulz, R. M. (2007). Why do countries matter so much for corporate governance? Journal of Financial Economics, 86(1), 1-39.

Doornik, J. A., \& Hendry, D. F. (2013). Econometric Modelling (PcGiveTM 14: Vol III), 6th ed., Timberlake Consultants Ltd, London, UK

Durnev, A., \& Kim, E. H. A. N. (2005). To steal or not to steal: Firm attributes, legal environment, and valuation. The Journal of Finance, 60(3), 1461-1493.

Enikolopov, R., Petrova, M., \& Stepanov, S. (2014). Firm value in crisis: Effects of firm-level transparency and country-level institutions. Journal of Banking \& Finance, 46, 72-84.

European Commission for the Efficiency of Justice (2016). European judicial systems. Efficiency and quality of justice. Edition 2016 (data 2014). CEPEJ Studies No. 23

Fama, E., \& French, K. (1993). Common risk factors in the returns on stocks and bonds, Journal of Financial Economics, 33(1), 3-56.

Fama, E., \& French, K. (1995). Size and book-to-market factors in earnings and returns. Journal of Finance 50, 131-155.

Fama, E., \& French, K/ (2002). The equity premium. The Journal of Finance, 57 (2), 637-659. 
Fama, E. F., \& French, K. (2015). Incremental variables and the investment opportunity set. Journal of Financial Economics, 117(3), 470-488.

Fan, J. P., Titman, S., \& Twite, G. (2012). An international comparison of capital structure and debt maturity choices. Journal of Financial and Quantitative Analysis, 47(1), 23-56.

Foye, J. Mramor, D., \& Pahor, M., (2013). A Respecified Fama French Three-Factor Model for the New European Union Member States. Journal of International Financial Management \& Accounting 24(1), 3-25,

Gao, C., Zuzul, T., Jones, G., \& Khanna, T. (2017). Overcoming Institutional Voids: A Reputation-Based View of Long-Run Survival. Strategic Management Journal, 38(11), 2147 2167.

Ghosh, S. (2007). Leverage, managerial monitoring and firm valuation: A simultaneous equation approach. Research in Economics, 61(2), 84-98.

Glaeser, E. L., La Porta, R., Lopez-de-Silanes, F., \& Shleifer, A. (2004). Do institutions cause growth? Journal of Economic Growth, 9(3), 271-303.

Grogan, L., \& Moers, L. (2001). Growth empirics with institutional measures for transition countries. Economic Systems, 25(4), 323-344.

Guiso, L., Sapienza, P., \& Zingales, L. (2004). The role of social capital in financial development. American Economic Review, 94(3), 526-556. 
Guiso, L., Sapienza, P., \& Zingales, L. (2008). Trusting the stock market. the Journal of Finance, 63(6), 2557-2600.

Hail, L., \& Leuz, C. (2006). International differences in the cost of equity capital: Do legal institutions and securities regulation matter? Journal of Accounting Research, 44(3), 485-531.

Hartwell, C.A. (2013). Institutional Barriers in the Transition to Market: Examining Performance and Divergence in Transition Economies. Basingstoke: Palgrave Macmillan.

Hartwell, C. A. (2014). Do (successful) stock exchanges support or hinder institutions in transition economies? Cogent Economics \& Finance 2: 946620: 1-18

Hartwell, C. (2016). Two Roads Diverge: The Transition Experience of Poland and Ukraine, Cambridge: Cambridge University Press,

Hayashi, F., \& Inoue, T. (1991). The Relation Between Firm Growth and Q with Multiple Capital Goods: Theory and Evidence from Panel Data on Japanese Firms. Econometrica, 59(3), $731-753$

Józefowicz, K. (2007). Taking on the Bailiff Monopoly in Poland. IFC Smart Lessons No. 10633, The World Bank Group, November.

Kaplan, S., \& Zingales, L. (1997). Do Investment-Cash Flow Sensitivities Provide Useful Measures of Financing Constraints? Quarterly Journal of Economics, 112(1), 169-215 
Khanna, T., \& Palepu, K. (1997). Why focused strategies may be wrong for emerging markets. Harvard Business Review, 75(4), 41-48.

Khanna, T., \& Palepu, K. (2000). The future of business groups in emerging markets: Longrun evidence from Chile. Academy of Management Journal, 43(3), 268-285.

Khanna, T., Palepu, K. G., \& Sinha, J. (2005). Strategies that fit emerging markets. Harvard Business Review, 83(6), 4-19.

Knyazeva, A., Knyazeva, D., \& Stiglitz, J. E. (2013). Ownership change, institutional development and performance. Journal of Banking \& Finance, 37(7), 2605-2627.

Konings, J. (2001). The effects of foreign direct investment on domestic firms. Economics of Transition, 9, 619-633.

Krishnaswami, S., \& Subramaniam, V. (1999). Information asymmetry, valuation, and the corporate spin-off decision. Journal of Financial Economics, 53(1), 73-112.

La Porta, R., Lopez-de-Silanes, F., Shleifer, A., \& Vishny, R. (2002). Investor protection and corporate valuation. The Journal of Finance, 57(3), 1147-1170.

Lanjouw, J. O., \& Levy, P. I. (2002). Untitled: A study of formal and informal property rights in urban Ecuador. The Economic Journal, 112(482), 986-1019. 
Lie, E. \& Lie, H.J. (2002). Multiples Used to Estimate Corporate Value. Financial Analysts Journal, 2 (58).

Malinowska, A. P. (2018): Polish firms' performance as a function of property rights and stock market developments. Paper presented at the SSEM EuroConference 2018: Emerging Market Economies, University of Lodz, Poland, June 7-8, 2018.

Maksimov, V., Wang, S. L., \& Luo, Y. (2017). Institutional imprinting, entrepreneurial agency, and private firm innovation in transition economies. Journal of World Business, 52, 854-865.

McMillan, J., \& Woodruff, C. (2002). The central role of entrepreneurs in transition economies. Journal of Economic Perspectives, 16(3), 153-170.

Minbaeva, D. B., \& Muratbekova-Touron, M. (2013). Clanism. Management International Review, 53(1), 109-139.

Pástor, L', \& Veronesi, P. (2003). Stock valuation and learning about profitability. The Journal of Finance, 58(5), 1749-1789.

Peng, M. W. (2003). Institutional transitions and strategic choices. Academy of Management Review, 28(2), 275-296.

Peng, M. W. (2006). Global Strategy. Cincinnati: South-Western Thomson 
Peng, M. W., Wang, D. Y., \& Jiang, Y. (2008). An institution-based view of international business strategy: A focus on emerging economies. Journal of International Business Studies, 39(5), 920-936.

Perfect, S. B., \& Wiles, K. W. (1994). Alternative constructions of Tobin's q: An empirical comparison. Journal of Empirical Finance, 1(3-4), 313-341.

Rodrik, D., Subramanian A., \& Trebbi F. (2004). Institutions rule: the primacy of institutions over geography and integration in economic development, Journal of Economic Growth, 9, $131-165$

Roodman, D. M. (2009): A note on the theme of too many instruments. Oxford Bulletin of Economics and Statistics 71: 135-158

Sauerwald, S., \& Peng, M. W. (2013). Informal institutions, shareholder coalitions, and principal-principal conflicts. Asia Pacific Journal of Management, 30(3), 853-870.

Stephan, U., Uhlaner, L. M., \& Stride, C. (2015). Institutions and social entrepreneurship: The role of institutional voids, institutional support, and institutional configurations. Journal of International Business Studies, 46(3), 308-331.

Tobin, J. (1969). A General Equilibrium Approach to Monetary Theory. Journal of Money Credit \& Banking, 1(1), 15-29. 
Tonoyan, V., Strohmeyer, R., Habib, M., \& Perlitz, M. (2010). Corruption and entrepreneurship: How formal and informal institutions shape small firm behavior in transition and mature market economies. Entrepreneurship theory and practice, 34(5), 803-832.

Varaiya, N., Kerin, R. A., \& Weeks, D. (1987). The relationship between growth, profitability, and firm value. Strategic Management Journal, 8(5), 487-497.

Voigt, S. (2013). How (not) to measure institutions. Journal of Institutional Economics, 9(1), $1-26$.

Williams, A., \& Siddique, A. (2008). The use (and abuse) of governance indicators in economics: A review. Economics of Governance, 9:131-175.

Williams, N., \& Vorley, T. (2015). Institutional asymmetry: how formal and informal institutions affect entrepreneurship in Bulgaria. International Small Business Journal, 33(8), $840-861$

Williamson, C. R., \& Kerekes, C. B. (2011). Securing private property: formal versus informal institutions. The Journal of Law and Economics, 54(3), 537-572.

Windmeijer, F. (2005). A finite sample correction for the variance of linear efficient two-step GMM estimators. Journal of Econometrics, 126(1): 25-51

World Bank (2015). Doing Business in Poland 2015. Washington, DC: World Bank 
Yasar, M., \& Morrison Paul, C. J. (2007). Firm Performance and Foreign Direct Investment: Evidence from Transition Economies. Economics Bulletin, 15(21) 1-11.

Yasar, M., Paul, C. J. M., \& Ward, M. R. (2011). Property rights institutions and firm performance: a cross-country analysis. World Development, 39(4), 648-661.

Zheng, X., El Ghoul, S., Guedhami, O., \& Kwok, C. C. (2012). National culture and corporate debt maturity. Journal of Banking \& Finance, 36(2), 468-488. 
Tables and Figures

Table 1: Baseline results

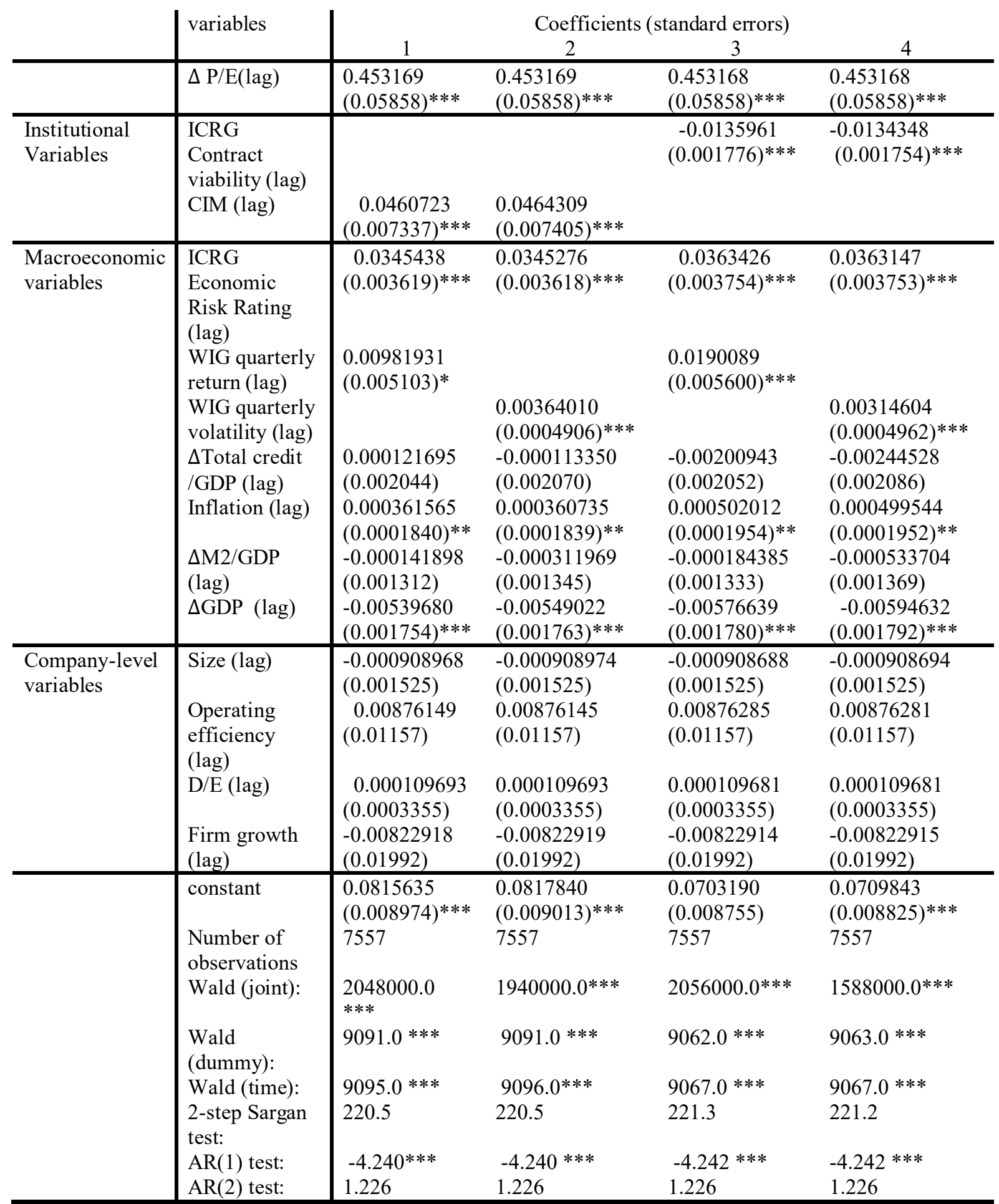

Note: ***, **, * indicate statistical significance at the 1\%, 5\% and $10 \%$ levels respectively. PcGive OxMetrics software does not yield Hansen statistics for SYS-GMM modelling (see Doornik and Hendry, 2013 for details). 
Table 2 Robustness analyses using both contract intensive money and ICRG Contract Viability as institutional metrics

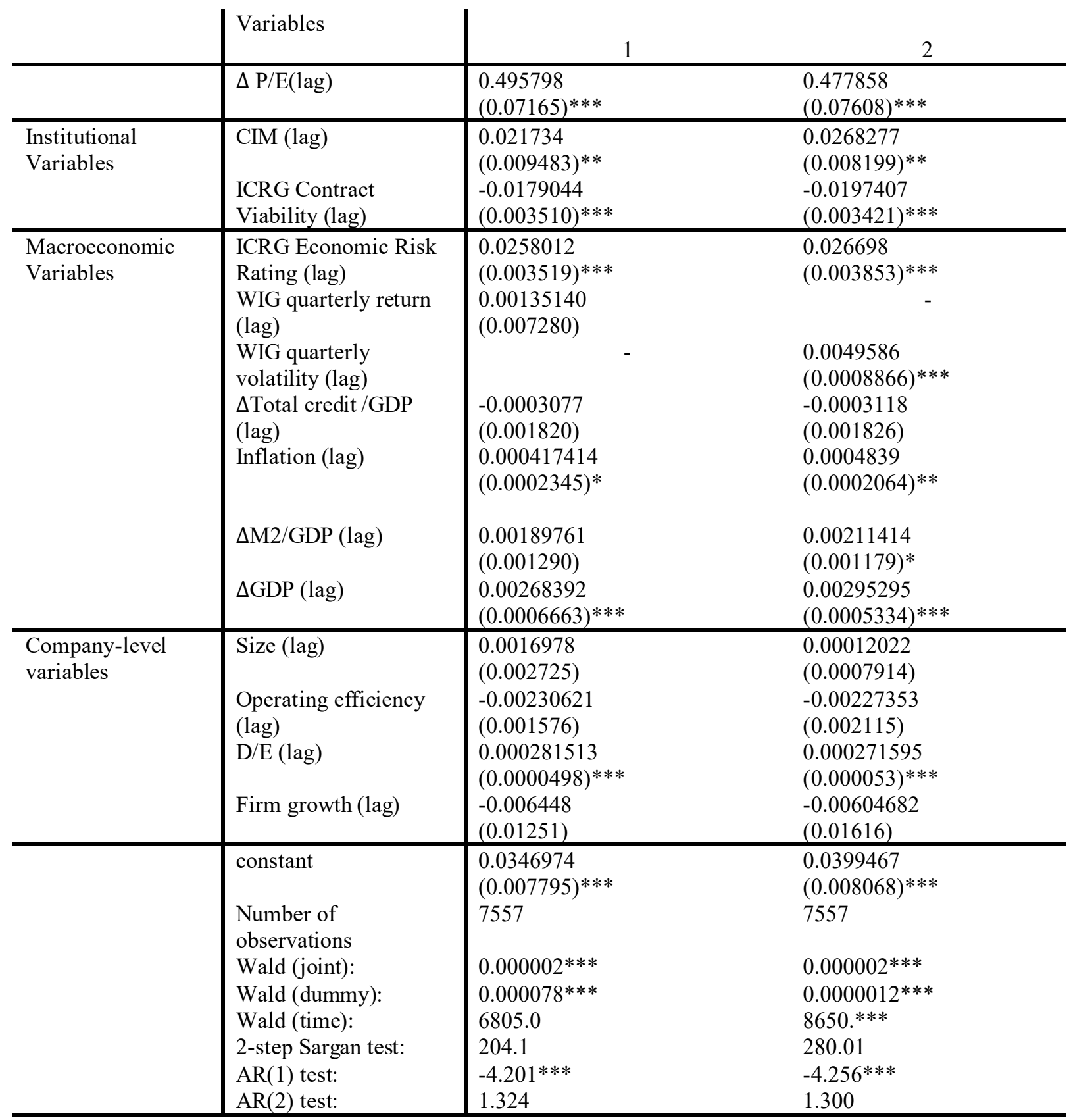

Note: $* * * * * *$ indicate statistical significance at the $1 \%, 5 \%$ and $10 \%$ levels respectively. 
Table 3: Robustness analyses using contract-intensive money as the property rights metric

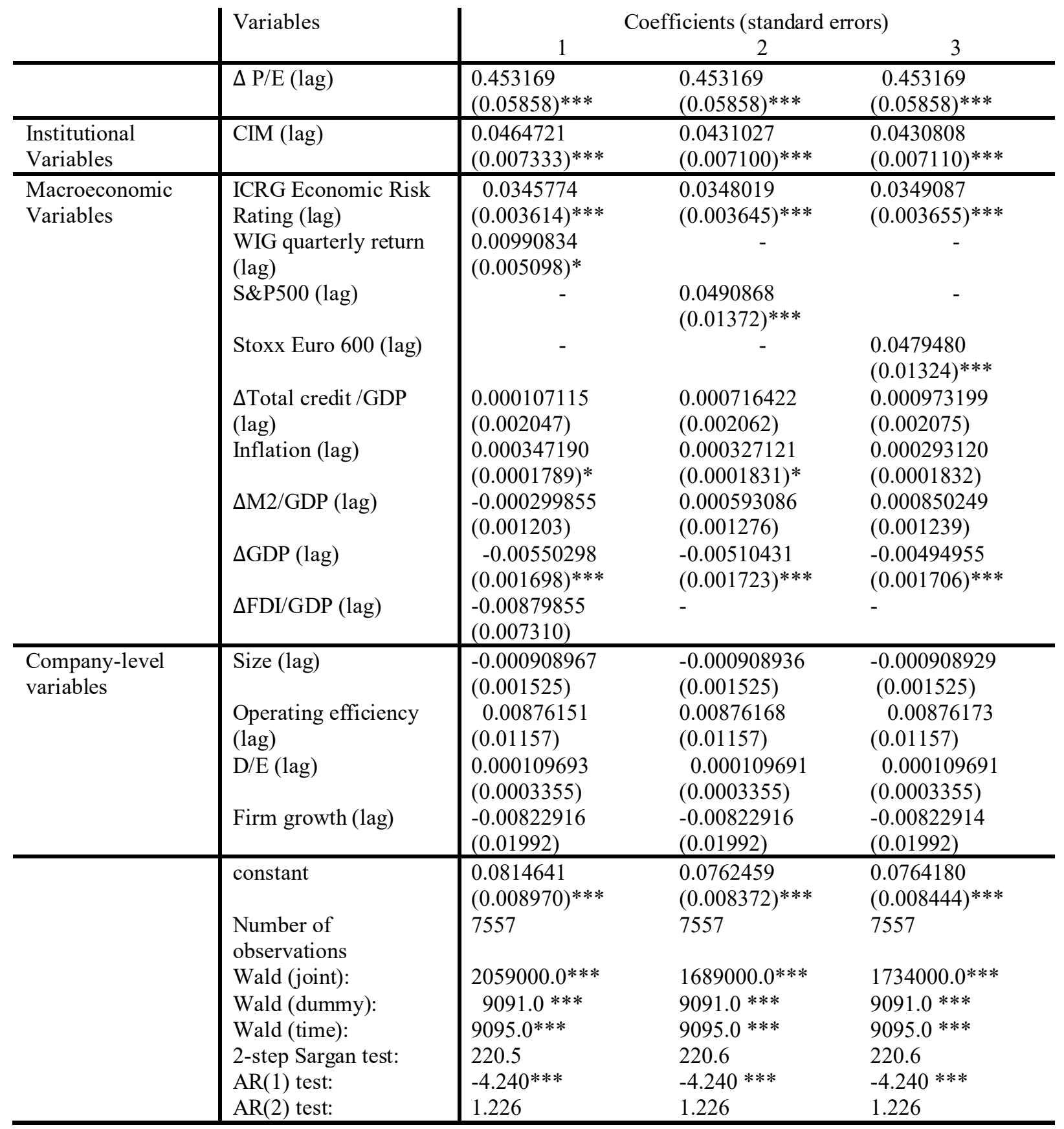


Table 4: Robustness analyses using ICRG contract viability as the property rights metric

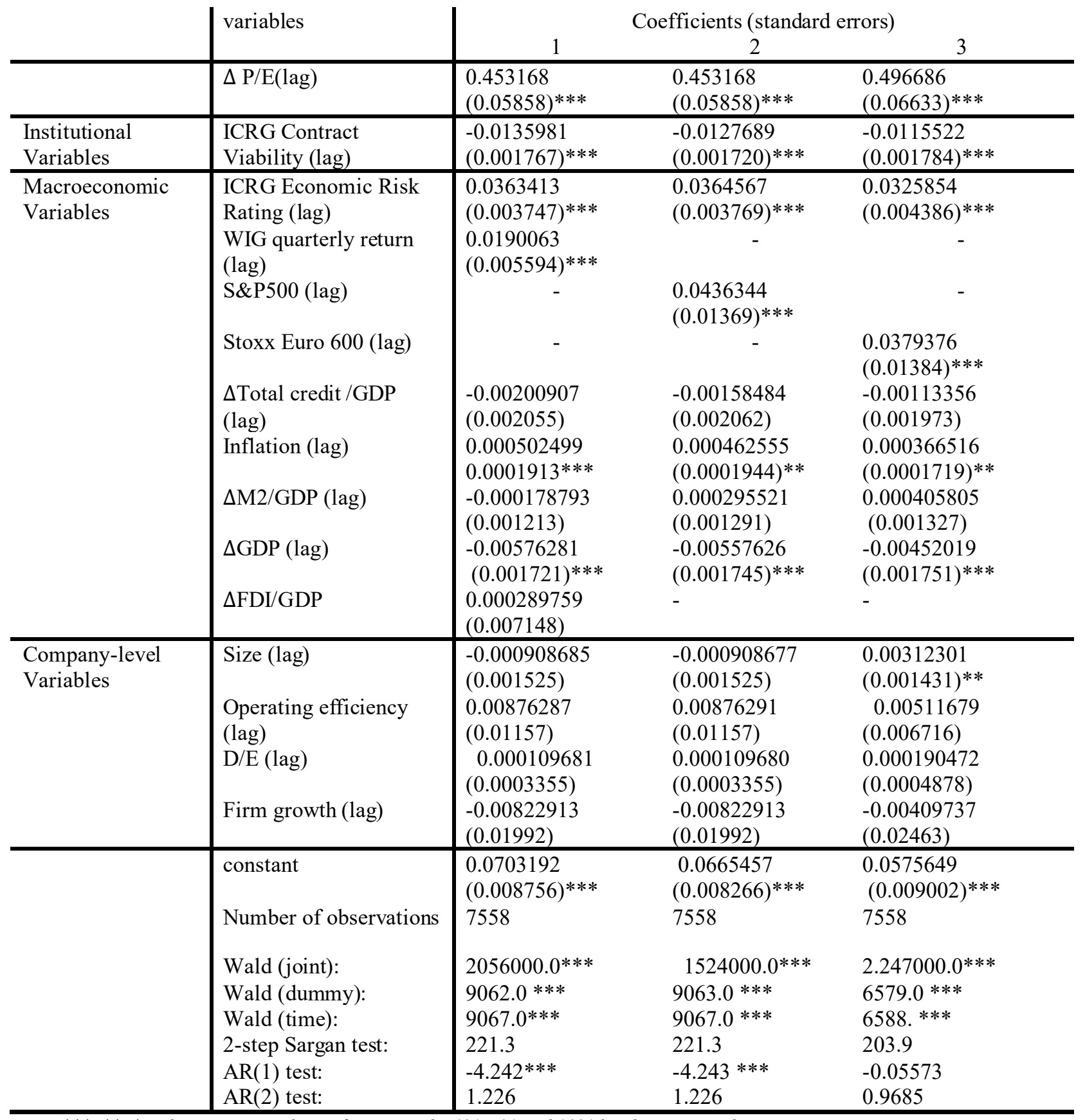


Figure 1: Informal Institutional Influence

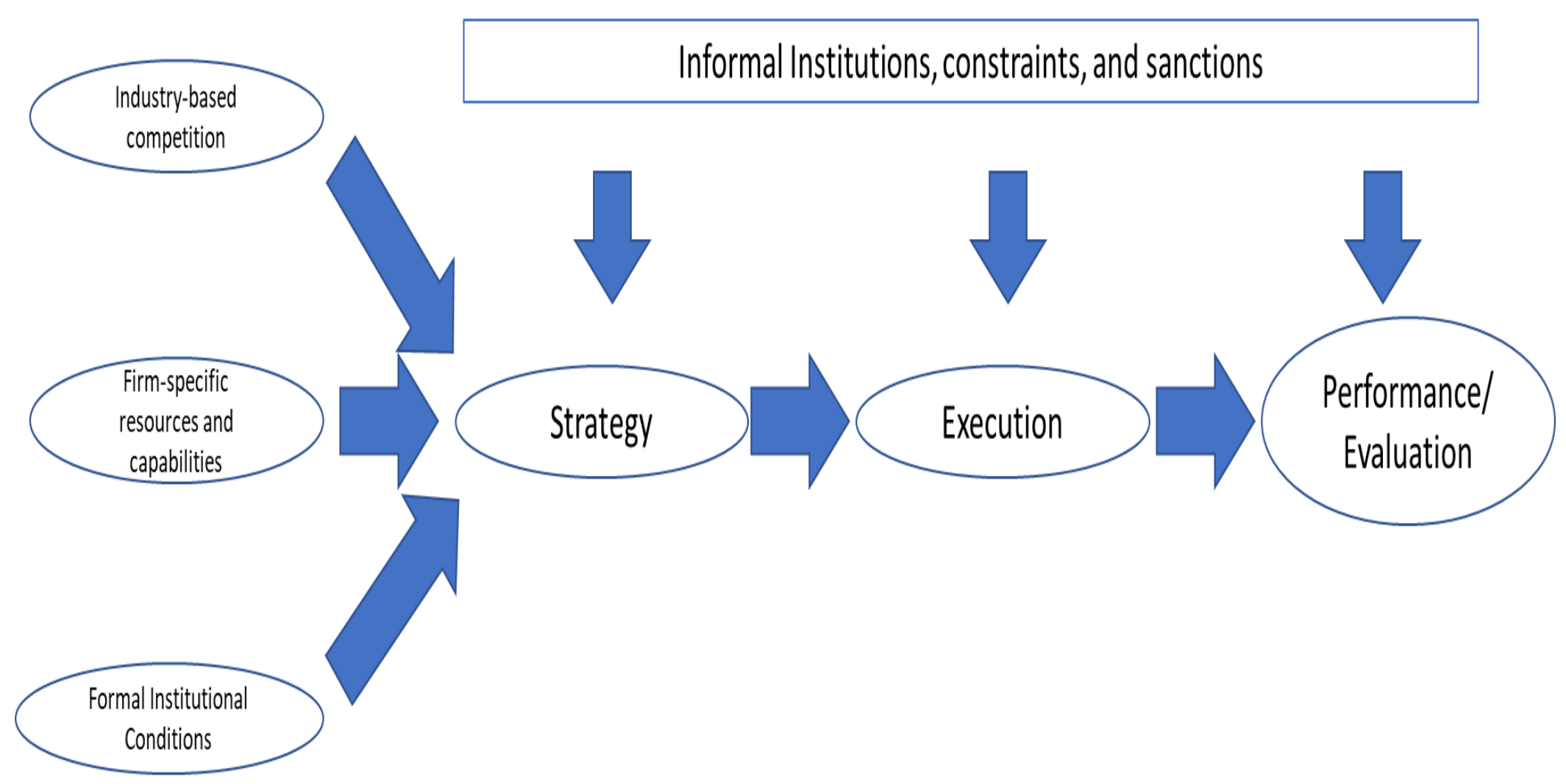

Note: Based on Peng (2006). 
Figure 2: Property rights in Poland, 2007-2015

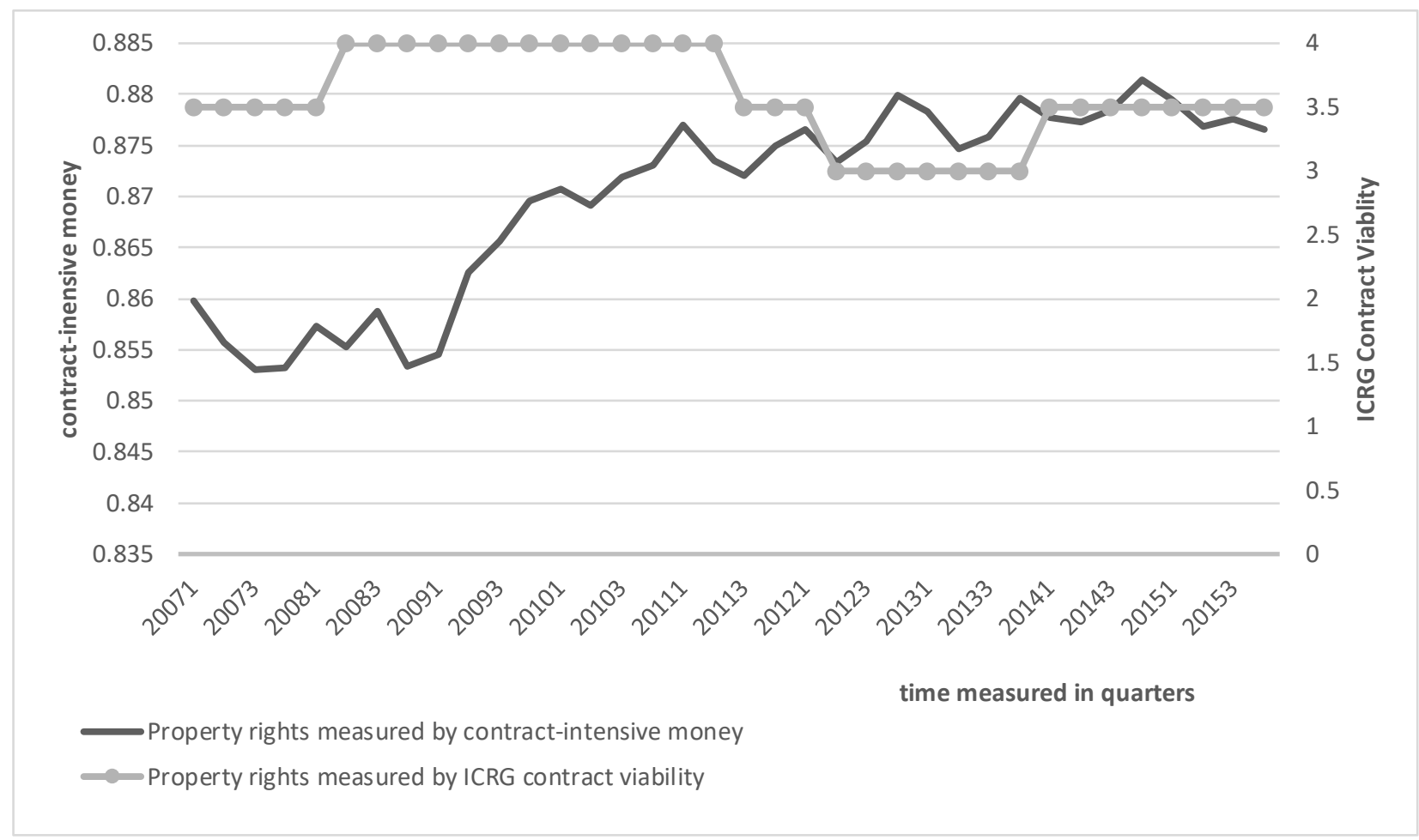

Sources: ICRG; the National Bank of Poland

Figure 3: International Country Risk Guide political risk rating for Poland, 2007-2015, and informal property rights

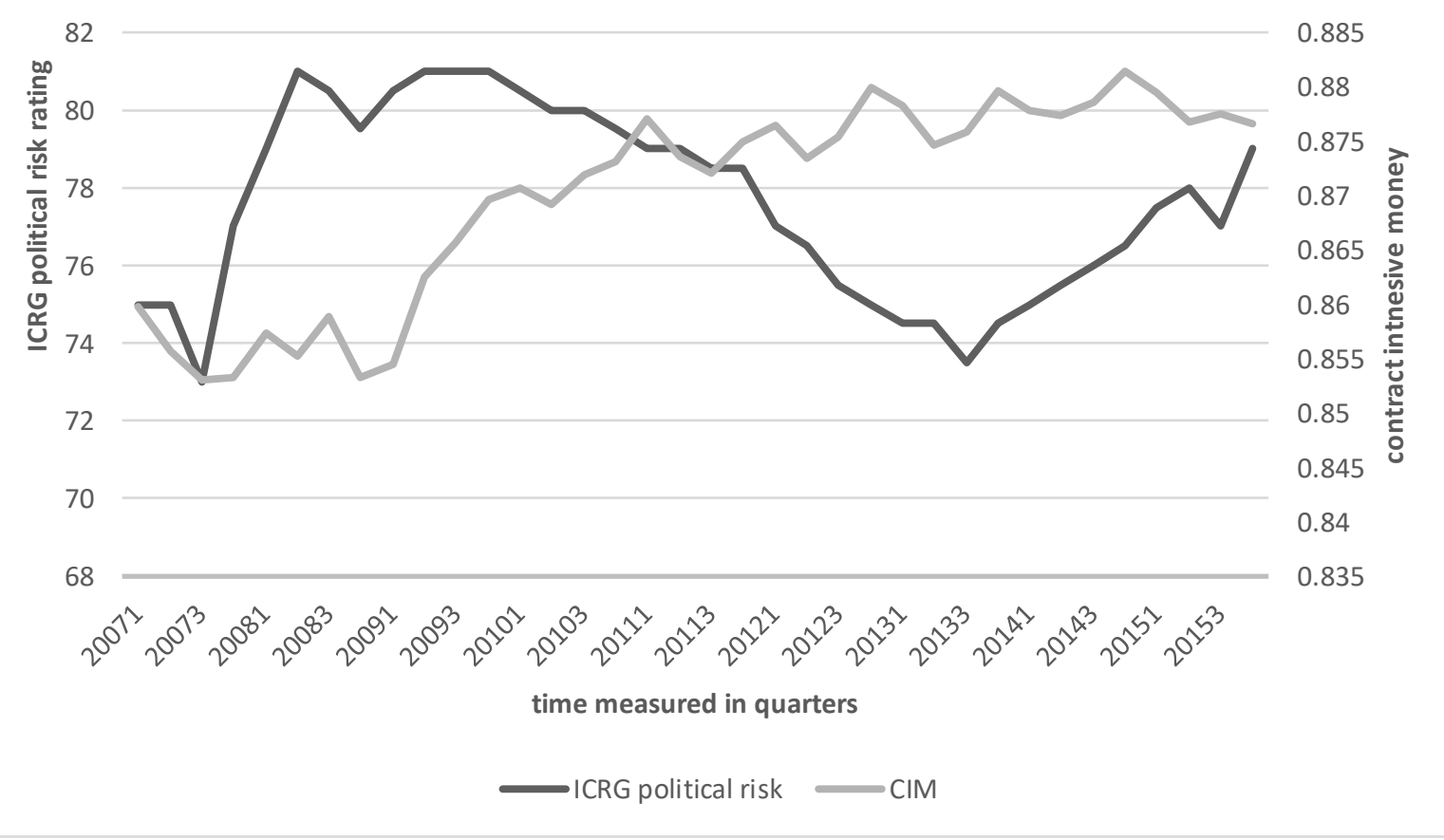

Source: ICRG database, author's estimates 


\section{APPENDIX A}

\section{Table A1 Summary statistics}

\begin{tabular}{|c|c|c|c|c|c|}
\hline & Variable & Mean & Maximum & Minimum & $\begin{array}{l}\text { Standard } \\
\text { deviation }\end{array}$ \\
\hline \multirow[t]{2}{*}{$\begin{array}{l}\text { Institutional } \\
\text { variables }\end{array}$} & $\begin{array}{l}\text { ICRG Contract Viability (ICRG } \\
\text { CV) }\end{array}$ & 3.34783 & 3.50000 & 3.0000 & 0.23007 \\
\hline & Contract intensive money (CIM) & 0.86969 & 0.87998 & 0.85305 & 0.00909 \\
\hline \multirow[t]{10}{*}{$\begin{array}{l}\text { Macroeconomic } \\
\text { variables }\end{array}$} & $\begin{array}{l}\text { ICRG Economic Risk Rating } \\
\text { (ICRG ERR) }\end{array}$ & 36.38571 & 39.50000 & 33.0000 & 1.71999 \\
\hline & $\begin{array}{l}\text { Quarterly stock market return } \\
\text { from the WIG overall index }\end{array}$ & -0.01333 & 0.20258 & -0.32759 & 0.10957 \\
\hline & $\begin{array}{l}\text { Quarterly market volatility of the } \\
\text { WIG overall index }\end{array}$ & 0.00948 & 0.02998 & 0.00224 & 0.00746 \\
\hline & S\&P 500 quarterly returns & 0.00871 & 0.10515 & -0.27159 & 0.07112 \\
\hline & Stoxx Euro 600 quarterly returns & 0.00004 & 0.16380 & -0.26270 & 0.09270 \\
\hline & $\begin{array}{l}\Delta \text { Domestic credit to the private } \\
\text { sector by banks }\end{array}$ & 0.00619 & 0.05001 & -0.05258 & 0.01675 \\
\hline & Inflation & 99.50000 & 101.8000 & 99.5000 & 0.71711 \\
\hline & $\Delta \mathrm{M} 2 / \mathrm{GDP}$ & 0.01406 & 0.04952 & -0.01887 & 0.01580 \\
\hline & GDP growth & 0.03514 & 0.07447 & -0.00029 & 0.01796 \\
\hline & FDI/GDP & 0.00124 & 0.17621 & -0.15124 & 0.09729 \\
\hline \multirow{5}{*}{$\begin{array}{l}\text { Company-level } \\
\text { variables }\end{array}$} & Size & 12.21308 & 17.64638 & 0.0000 & 2.50080 \\
\hline & Operating efficiency & 0.67945 & 1.37787 & -72.6000 & 0.92489 \\
\hline & $\mathrm{D} / \mathrm{E}$ & 0.14853 & 6.98038 & -5386.3300 & 62.89675 \\
\hline & Firm growth & -0.01003 & 1.27429 & -7.43189 & 0.42428 \\
\hline & $\mathrm{P} / \mathrm{E}$ & 1.48980 & 12.98000 & 0.0000 & 1.63510 \\
\hline
\end{tabular}

Note A1: Data retrieved from the sources listed in the text; transformed in order to eliminate the outlying observations - see Section 3 for details. Where possible, data is rounded up to the 5th decimal place

Figure A1 ICRG metrics vs Poland market risk

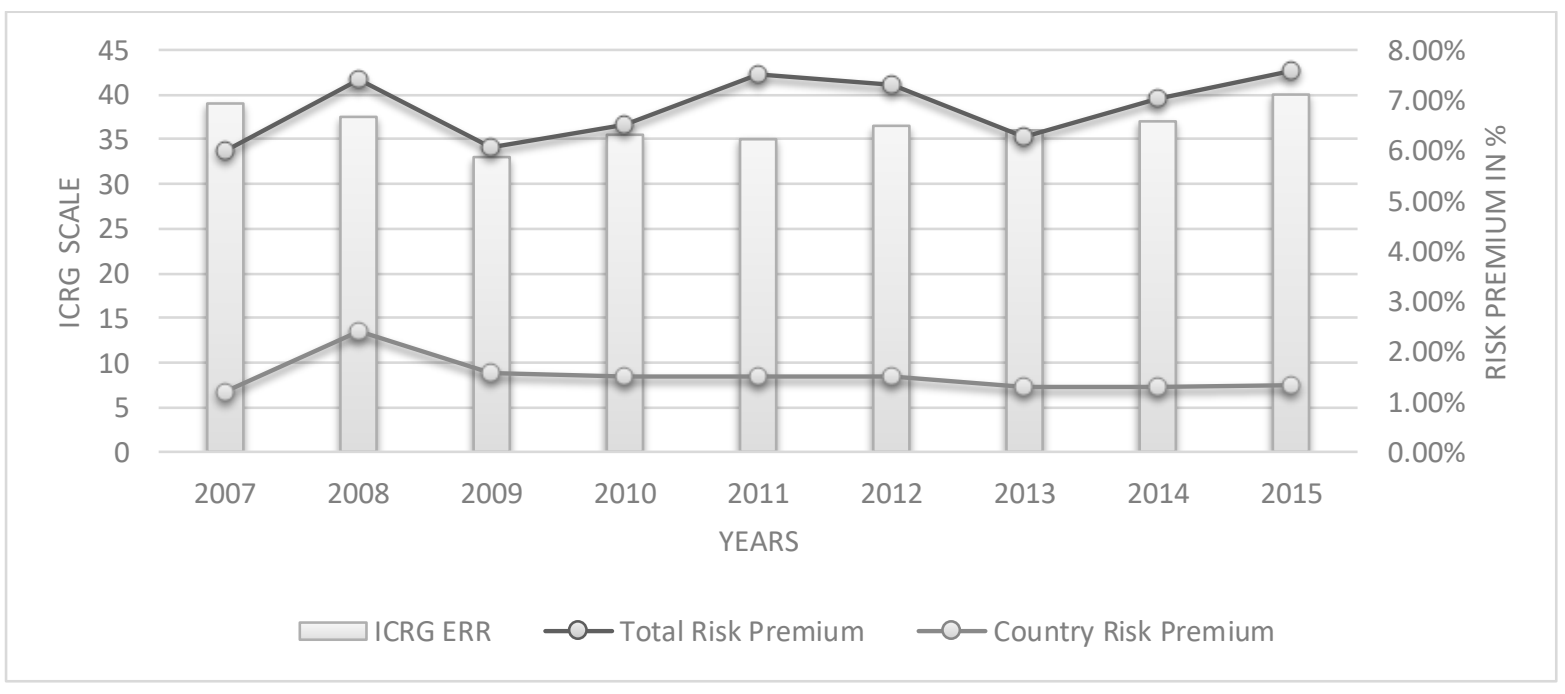

Note A2 Data retrieved from the ICRG database and A. Damodaran online repository (http://pages.stern.nyu.edu/ adamodar/New_Home_Page/datacurrent.html accessed 19th May 2018) 
Table A2 Variable description and source

\begin{tabular}{|c|c|c|c|}
\hline & Variable & Comments & Data source \\
\hline \multirow[t]{2}{*}{$\begin{array}{l}\text { Institutional } \\
\text { Variables }\end{array}$} & $\begin{array}{l}\text { ICRG Contract } \\
\text { Viability (ICRG CV) }\end{array}$ & $\begin{array}{l}\text { It presents property rights and how secureable they are as a function of the coutnry's legislation } \\
\text { related to ownership of property and its danger of being expropriated by the ruling government; } \\
\text { scores from } 0 \text { to } 4 \text { - where higher numbers reflect stronger property rights. }\end{array}$ & ICRG \\
\hline & $\begin{array}{l}\text { Contract intensive } \\
\text { money (CIM) }\end{array}$ & Calculated as M2 less money held outside the banking sector relative to all M2. & $\begin{array}{l}\text { Author's own calculations } \\
\text { based on data from the } \\
\text { National Bank of Poland }\end{array}$ \\
\hline \multirow[t]{10}{*}{$\begin{array}{l}\text { Macroeconomic } \\
\text { Variables }\end{array}$} & $\begin{array}{l}\text { ICRG Economic Risk } \\
\text { Rating (ICRG ERR) }\end{array}$ & $\begin{array}{l}\text { It proxies for economic risk, with lower scores translating to higher economic risk and volatility; it } \\
\text { combines measures such as but not limited to Current Account as a Percentage of GDP, GDP per } \\
\text { Head, and Budget Balance as a Percentage of GDP (for a full methodological disclosure International } \\
\text { Country Risk Guide Methodology p. 8). }\end{array}$ & ICRG \\
\hline & $\begin{array}{l}\text { Quarterly stock } \\
\text { market return from } \\
\text { the WIG overall } \\
\text { index }\end{array}$ & It captures quarterly return rates from the domestic market. & Stooq \\
\hline & $\begin{array}{l}\text { Quarterly market } \\
\text { volatility of the } \\
\text { overall index }\end{array}$ & Calculated as in Hartwell (2014) & Stooq \\
\hline & $\begin{array}{l}\text { S\&P } 500 \text { quarterly } \\
\text { returns }\end{array}$ & It captures quarterly return rates from the US benchmark stock market. & $\begin{array}{l}\text { Marketwatch and The FRED } \\
\text { St Louis Fed Economic } \\
\text { Database }\end{array}$ \\
\hline & $\begin{array}{l}\text { Stoxx Euro } 600 \\
\text { quarterly returns }\end{array}$ & It captures quarterly return rates from the Pan-European benchmark stock market. & Marketwatch \\
\hline & $\begin{array}{l}\Delta \text { Domestic credit to } \\
\text { the private sector by } \\
\text { banks }\end{array}$ & $\begin{array}{l}\text { Total bank credit to firms and households as percent of GDP, it proxies for the development of the } \\
\text { banking system. }\end{array}$ & $\begin{array}{l}\text { The FRED St Louis Fed } \\
\text { Economic Database }\end{array}$ \\
\hline & Inflation & $\begin{array}{l}\text { Calculated as quarterly change in the index, set to capture the central bank's approach to } \\
\text { macroeconomic policy. }\end{array}$ & $\begin{array}{l}\text { The FRED St Louis Fed } \\
\text { Economic Database }\end{array}$ \\
\hline & $\Delta \mathrm{M} 2 / \mathrm{GDP}$ & $\begin{array}{l}\text { Log change in M2 scaled by domestic GDP; set to capture the government's approach to sound } \\
\text { money and macroeconomic management }\end{array}$ & $\begin{array}{l}\text { Authors' own calculations } \\
\text { based on data from the } \\
\text { National Bank of Poland }\end{array}$ \\
\hline & GDP growth & It captures the general dynamic of domestic growth, quarter-to-quarter. & $\begin{array}{l}\text { The FRED St Louis Fed } \\
\text { Economic Database }\end{array}$ \\
\hline & $\Delta \mathrm{FDI} / \mathrm{GDP}$ & $\begin{array}{l}\text { Calculated as log change in FDI scaled by domestic GDP; proxies for the economy's degree of } \\
\text { openness to foreign capital and innovation. }\end{array}$ & $\begin{array}{l}\text { Author's own calculations } \\
\text { based on data retrieved from }\end{array}$ \\
\hline
\end{tabular}




\begin{tabular}{|l|l|l|l|}
\hline & & & $\begin{array}{l}\text { the Central Statistical Office } \\
\text { (??) }\end{array}$ \\
\hline $\begin{array}{l}\text { Company-level } \\
\text { variables }\end{array}$ & Size & Natural logarithm of total assets. & $\begin{array}{l}\text { Authors' own calculations } \\
\text { based on data from NOTORIA }\end{array}$ \\
\cline { 2 - 4 } & D/E & Calculated as a debt-to-equity ratio & $\begin{array}{l}\text { Authors' own calculations } \\
\text { based on data from NOTORIA }\end{array}$ \\
\cline { 2 - 5 } & Operating efficiency & $\begin{array}{l}\text { Calculated as an operating expenses-to-net-sales ratio; it captures the efficiency of a company's } \\
\text { management - the lower the ratio, the greater the firm's ability to record profits if revenues from } \\
\text { sales plummet. }\end{array}$ & $\begin{array}{l}\text { Authors' own calculations } \\
\text { based on data from NOTORIA }\end{array}$ \\
\cline { 2 - 5 } & Firm growth & Calculated as \% change of sales (quarter-to-quarter) & $\begin{array}{l}\text { Authors' own calculations } \\
\text { based on data from NOTORIA }\end{array}$ \\
\cline { 2 - 5 } & $\begin{array}{l}\text { Firm price-to- } \\
\text { earnings value (P/E) }\end{array}$ & $\begin{array}{l}\text { It denotes change in relative firm market value (expressed as a log change in company price-to- } \\
\text { earnings ratio (P/BV) measured year-over-year. }\end{array}$ & $\begin{array}{l}\text { Authors' own calculations } \\
\text { based on data from Stooq }\end{array}$ \\
\hline
\end{tabular}


Table A3 Correlation matrix

\begin{tabular}{|c|c|c|c|c|c|c|c|c|c|c|c|c|c|c|c|c|}
\hline & $\begin{array}{r}\text { Euro } \\
\text { Stoxx } \\
600\end{array}$ & S\&P500 & $\begin{array}{r}\text { GDP } \\
\text { growth }\end{array}$ & $\begin{array}{r}\text { ICRG } \\
\text { ERR }\end{array}$ & $\begin{array}{r}\text { ICRG } \\
\text { CV }\end{array}$ & Inflation & CIM & $\begin{array}{l}\text { Total } \\
\text { credit }\end{array}$ & $\begin{array}{r}\Delta \mathrm{M} 2 / \mathrm{GD} \\
\mathrm{P}\end{array}$ & $\begin{array}{l}\text { Market } \\
\text { vol. }\end{array}$ & $\begin{array}{l}\text { WIG } \\
\text { return }\end{array}$ & $\mathrm{D} / \mathrm{E}$ & $\mathrm{OE}$ & $\begin{array}{r}\text { Firm } \\
\text { Growth }\end{array}$ & Size & FDI \\
\hline EuroStoxx600 & 1.00 & 0.801 & -0.107 & -0.177 & 0.126 & -0.003 & 0.023 & -0.403 & -0.139 & -0.314 & 0.727 & -0.003 & -0.007 & -0.011 & 0.047 & -0.034 \\
\hline S\&P500 & & 1.00 & -0.047 & -0.092 & 0.118 & -0.175 & 0.013 & -0.349 & -0.051 & -0.259 & 0.617 & -0.004 & -0.011 & -0.001 & 0.065 & -0.010 \\
\hline GDP growth & & & 1.00 & -0.202 & 0.131 & -0.133 & -0.021 & 0.003 & 0.189 & 0.169 & -0.002 & -0.002 & -0.0109 & 0.022 & 0.068 & -0.215 \\
\hline ICRG ERR & & & & 1.00 & -0.009 & 0.003 & -0.057 & 0.171 & -0.202 & 0.021 & 0.034 & -0.005 & 0.008 & -0.022 & -0.006 & 0.288 \\
\hline ICRG CV & & & & & 1.00 & 0.210 & -0.124 & -0.144 & 0.121 & -0.135 & 0.086 & -0.011 & 0.009 & -0.001 & 0.010 & 0.049 \\
\hline Inflation & & & & & & 1.00 & -0.029 & 0.055 & 0.024 & 0.144 & -0.048 & -0.002 & -0.007 & 0.087 & -0.022 & -0.264 \\
\hline CIM & & & & & & & 1.00 & -0.121 & -0.235 & 0.114 & 0.083 & -0.003 & 0.003 & -0.023 & -0.014 & 0.174 \\
\hline Total credit & & & & & & & & 1.00 & 0.208 & 0.318 & -0.367 & 0.032 & 0.003 & 0.013 & -0.036 & -0.010 \\
\hline$\Delta \mathrm{M} 2 / \mathrm{GDP}$ & & & & & & & & & 1.00 & 0.182 & -0.321 & 0.012 & -0.011 & 0.102 & -0.024 & -0.413 \\
\hline Market vol. & & & & & & & & & & 1.00 & -0.268 & 0.001 & 0.004 & -0.011 & -0.099 & 0.185 \\
\hline WIG return & & & & & & & & & & & 1.00 & -0.001 & -0.012 & -0.005 & -0.006 & 0.069 \\
\hline $\mathrm{D} / \mathrm{E}$ & & & & & & & & & & & & 1.00 & -0.001 & 0.004 & -0.017 & 0.0215 \\
\hline $\mathrm{OE}$ & & & & & & & & & & & & & 1.00 & 0.022 & 0.068 & 0.011 \\
\hline Firm Growth & & & & & & & & & & & & & & 1.00 & 0.020 & -0.215 \\
\hline Size & & & & & & & & & & & & & & & 1.00 & -0.040 \\
\hline FDI & & & & & & & & & & & & & & & & 1.00 \\
\hline
\end{tabular}


Table A4 Stationarity test results

\begin{tabular}{|c|c|c|}
\hline & variable & ADF Test results \\
\hline \multirow[t]{2}{*}{ Institutional Variables } & $\begin{array}{l}\text { ICRG Contract Viability } \\
\text { (ICRG CV) }\end{array}$ & $\begin{array}{l}\text { Choi meta-tests: } \\
\text { Inverse chi-squared(48) }=2785.06^{* * *} \\
\text { Inverse normal test }=-51.2177 * * * \\
\text { test Logit: } \mathrm{t}(124)=-157.994 * * *\end{array}$ \\
\hline & $\begin{array}{ll}\text { Contract } & \text { intensive } \\
\text { money (CIM) } & \end{array}$ & $\begin{array}{l}\text { Choi meta-tests: } \\
\text { Inverse chi-squared }(48)=3589.56^{* * *} \\
\text { Inverse normal test }=-58.4409^{* * *} \\
\text { test Logit: } \mathrm{t}(124)=-203.633^{* * *}\end{array}$ \\
\hline \multirow[t]{10}{*}{$\begin{array}{l}\text { Macroeconomic } \\
\text { Variables }\end{array}$} & $\begin{array}{l}\text { ICRG Economic Risk } \\
\text { Rating (ICRG ERR) }\end{array}$ & $\begin{array}{l}\text { Choi meta-tests: } \\
\text { Inverse chi-squared }(48)=3250.27 * * * \\
\text { Inverse normal test }=-55.1758^{* * *} \\
\text { test Logit: } \mathrm{t}(124)=-184.385^{* * *}\end{array}$ \\
\hline & $\begin{array}{l}\text { Quarterly stock market } \\
\text { return from the WIG } \\
\text { overall index }\end{array}$ & $\begin{array}{l}\text { Choi meta-tests: } \\
\text { Inverse chi-squared }(48)=4462.39 * * * \\
\text { Inverse normal test }=-65.1464 * * * \\
\text { test Logit: } \mathrm{t}(124)=-253.147 * * *\end{array}$ \\
\hline & $\begin{array}{l}\text { Quarterly market } \\
\text { volatility of the overall } \\
\text { index }\end{array}$ & $\begin{array}{l}\text { Choi meta-tests: } \\
\text { Inverse chi-squared }(48)=3615.94 * * * \\
\text { Inverse normal test }=-58.6853 * * * \\
\text { test Logit: } \mathrm{t}(124)=-205.129 * * *\end{array}$ \\
\hline & $\begin{array}{lll}\text { S\&P } & 500 & \text { quarterly } \\
\text { returns } & & \\
\end{array}$ & $\begin{array}{l}\text { Choi meta-tests: } \\
\text { Inverse chi-squared }(48)=4449.74 * * * \\
\text { Inverse normal test }=-64.9323 * * * \\
\text { test Logit: } \mathrm{t}(124)=-252.43^{* * *}\end{array}$ \\
\hline & $\begin{array}{lcc}\text { Stoxx } & \text { Euro } & 600 \\
\text { quarterly returns } & \end{array}$ & $\begin{array}{l}\text { Choi meta-tests: } \\
\text { Inverse chi-squared }(48)=4572.26^{* * *} \\
\text { Inverse normal test }=-66.2013 * * * \\
\text { test Logit: } \mathrm{t}(124)=-259.381 * * *\end{array}$ \\
\hline & $\begin{array}{l}\Delta \text { Domestic credit to the } \\
\text { private sector by banks }\end{array}$ & $\begin{array}{l}\text { Choi meta-tests: } \\
\text { Inverse chi-squared }(48)=4669.7^{* * *} \\
\text { Inverse normal test }=-66.5214^{* * *} \\
\text { test Logit: } \mathrm{t}(124)=-264.908^{* * *}\end{array}$ \\
\hline & Inflation & $\begin{array}{l}\text { Choi meta-tests: } \\
\text { Inverse chi-squared }(48)=3929.000^{* * *} \\
\text { Inverse normal test }=-61.1716^{* * *} \\
\text { test Logit: } \mathrm{t}(124)=-222.889^{* * *} \\
\end{array}$ \\
\hline & $\Delta \mathrm{M} 2 / \mathrm{GDP}$ & $\begin{array}{l}\text { Choi meta-tests: } \\
\text { Inverse chi-squared }(48)=3947.9^{* * *} \\
\text { Inverse normal test }=-60.872^{* * *} \\
\text { test Logit: } \mathrm{t}(124)=-223.961^{* * *} \\
\end{array}$ \\
\hline & GDP growth & $\begin{array}{l}\text { Choi meta-tests: } \\
\text { Inverse chi-squared }(48)=31.9421^{*} \\
\text { Inverse normal test }=0722463^{*} \\
\text { test Logit: } \mathrm{t}(124)=0.645569^{*}\end{array}$ \\
\hline & $\Delta \mathrm{FDI} / \mathrm{GDP}$ & $\begin{array}{l}\text { Choi meta-tests: } \\
\text { Inverse chi-squared }(48)=4410.16^{* * *} \\
\text { Inverse normal test }=-64.1673^{* * *} \\
\text { test Logit: } \mathrm{t}(124)=-250.185^{* * *}\end{array}$ \\
\hline \multirow[t]{4}{*}{$\begin{array}{l}\text { Company-level } \\
\text { variables }\end{array}$} & Size & $\begin{array}{l}\text { Choi meta-tests: } \\
\text { Inverse chi-squared }(48)=972.844^{* * *} \\
\text { Inverse normal test }=-28.4434^{* * *} \\
\text { test Logit: } \mathrm{t}(124)=-55.1885^{* * *}\end{array}$ \\
\hline & $\mathrm{D} / \mathrm{E}$ & $\begin{array}{l}\text { Choi meta-tests: } \\
\text { Inverse chi-squared }(48)=1650.01 * * * \\
\text { Inverse normal test }=-37.7054^{* * *} \\
\text { test Logit: } \mathrm{t}(124)=-93.6035^{* * *}\end{array}$ \\
\hline & Operating efficiency & $\begin{array}{l}\text { Choi meta-tests: } \\
\text { Inverse chi-squared }(48)=967.554 * * * \\
\text { Inverse normal test }=-27.7234^{* * *} \\
\text { test Logit: } \mathrm{t}(124)=-54.8884 * * *\end{array}$ \\
\hline & Firm growth & $\begin{array}{l}\text { Choi meta-tests: } \\
\text { Inverse chi-squared }(48)=2050.76 * * * \\
\text { Inverse normal test }=-43.2405^{* * *}\end{array}$ \\
\hline
\end{tabular}




\begin{tabular}{|l|l|l|}
\hline & & test Logit: $\mathrm{t}(124)=-116.338 * * *$ \\
\cline { 2 - 3 } & Firm price-to-earnings & Choi meta-tests: \\
value (P/E) & $\begin{array}{l}\text { Inverse chi-squared }(48)=3034.43 * * * * \\
\text { Inverse normal test }=-53.6152 * * * \\
\text { test Logit: } \mathrm{t}(124)=-172.141 * * *\end{array}$ \\
\hline
\end{tabular}

Note A3; ***, **, * indicate statistical significance at the $1 \%, 5 \%$ and $10 \%$ levels respectively 


\section{APPENDIX B - A NOTE ON TOBIN'S Q}

Research in the fields of corporate finance focused on firm market value and corporate and regulatory phenomena have been relying for decades on what is commonly as Tobin's q as an appropriate proxy for firm value. Looking back at the original formulation of Tobin's q and its intended role in meanreverting metric modelling macroeconomic investment policy, and the structural changes the metric has undergone since its beginnings, it becomes apparent that the current version of (so-called) Tobin's q does not capture what law and finance researchers claim it does.

Indeed, the original Tobin's q meant to capture market valuation of equities, relative to the replacement cost of the physical assets they represent, as the key determinant of investment. Tobin himself argued that the key insight stemming from the introduction of q could be associated with monetary policy: the major channel of impacting the aggregate demand via monetary policy was "by changing the valuation of physical assets relative to their replacement costs"(Tobin, 1969:29) In this context, Tobin's initial metric related to macroeconomics and remained irrelevant in terms of capturing the consequences of changes in policy or shocks on relative prices, instead emerging as a potential lever which could be applied to induce changes in the aggregate.

Understood as such, the metric, when high, meant that the market value of an asset held by an entity was greater than its replacement cost. If this claim were accurate, and the entity in question could increase the scale of its operations, it should follow that the firm should invest in this particular kind of assets - and continue to do so, until their market value becomes equal to their replacement costs (i.e., $\mathrm{q}=1$ ). In this light it does not follow that firms with relatively high q-metrics also have high market value or that they would retain a high level of q. Indeed, in line with Tobin's original line of thought, the q of any company should revert to unity in the future. More importantly, form the perspective of corporate finance, to the extent the market value of a firm's assets dwarfs their replacement value, firms with high q are likely to face decreasing profit opportunities. 
Obviously, since its launch in the 1960s and 1970s, the index has morphed as a result of conceptual differences in its use in macroeconomics and corporate finance. Indeed, the matters were taken much further down the road with scholars adopting diverging definitions of the metric. With the fault line between the two groups falling at the issue whether the macroeconomic approach or the finance approach was being examined, the former group examined the effects of $q$ on investment behaviour utilising q defined as the ratio of the market value of a firm's stock of tangible capital to the replacement value of the said stock, aligning with Tobin's original approach. On the other hand, corporate finance research perceived q as the ratio of the market value of the firm's outstanding securities to the cost of replacing of all of the firm's assets, not limited to its physical assets. This change was understandable, given the prevalent assumption that, in corporate finance, q could well approximate a firm's overall performance and value.

This broader interpretation of q, while intuitively appealing, diverged significantly from Tobin's theory: indeed, Brainard and Tobin (1968:9) had suggested that "[t]here are many kinds of physical capital and many markets where existing stocks are valued," a statement explicitly suggesting that in an ideal world, each type of assets should possess a different, own, q metric. In the same vein, Hayashi and Inoue (1991:732) had claimed that "one has to invoke a very stringent set of assumptions including the Hicks aggregation condition [that all of the firm's assets are perfect substitutes in the production process] to derive a one-to-one relation between the sum of investments and $\mathrm{Q}$ that is independent of the composition of investments." In this context, the enthusiastic approach to measuring of the firm value by the means of aggregation of assets which could be as dissimilar as, e.g., capital goods, good will, or cash and equivalents, is bound to fail this condition. Put differently, while macroeconomic analyses based on q and focused on investment specifically were less concerned about lumping together different kinds of assets, the strand of research dealing with corporate finance adopted the q metric as a manner of analysing a company assets in the aggregate - regardless of their nature - becoming comfortable to group dissimilar categories of assets in one measure. 
Thus, the metric evolved into a more simplified, if not simplistic form, turning the original into something close to a company market-to-book ratio with book value substituted for market value of preferred and debt securities: q = (MVE + PS + DEBT $) /$ TA where MVE represents a firm's share price times the number of its common shares outstanding, PS is its liquidating value of any outstanding preferred stock, DEBT approximates the value of its short-term liabilities net of its short-term assets augmented by the book value of long-term debt, and TA is the book value of its total assets. Widely cited studies (cf. Kaplan and Zinglaes 1997 or Perfect and Wiles 1994) used an even less complicated (calculation-wise) method, stating that Tobin's q be equal to firm's $(A T+M V E-B V-D T) / A T$ with AT equal to the book value of assets, MVE being the market value of common stock, BVE approximating the book value of common equity, and DT being balance sheet value of deferred taxes. With passing time, the q simplified even more, with Bharath, Jayaraman, and Nagar (2013:2524) defining it "as the ratio of the market value of assets divided by the book value of assets, both computed at the end of each fiscal year." ${ }^{22}$ This is precisely the measure we used in the paper.

\footnotetext{
${ }^{22}$ For a further, in-depth discussion of the evolution of $\mathrm{q}$ and its misuses see Bartlett and Partnoy (2018).
} 